\title{
Identification of Morphine- and Cyclic AMP-Regulated Phosphoproteins (MARPPs) in the Locus Coeruleus and Other Regions of Rat Brain: Regulation by Acute and Chronic Morphine
}

\author{
Xavier Guitart ${ }^{\mathrm{a}}$ and Eric J. Nestler \\ Laboratory of Molecular Psychiatry, Departments of Psychiatry and Pharmacology, Yale University School of Medicine \\ and Connecticut Mental Health Center, New Haven, Connecticut 06508
}

Regulation of CAMP-dependent protein phosphorylation by acute and chronic morphine was studied in the rat locus coeruleus (LC), a brain region that appears to play an important role in mediating morphine action in animals, including humans. Rats were treated chronically with morphine under conditions known to induce states of tolerance and dependence. Protein phosphorylation was then studied in extracts of LC and other brain regions with back-phosphorylation assays under different conditions and with 1- and 2dimensional electrophoretic procedures. Evidence was obtained to suggest that chronic morphine increased the phosphorylation state of proteins of 165,55 , and 14-20 kDa and Increased the total amount of proteins of $145,71,62,58$, and $51 \mathrm{kDa}$ in the LC. Concomitant treatment of rats with naltrexone, an opiate receptor antagonist, blocked the ability of morphine to influence each of these proteins, indicating that morphine regulation of protein phosphorylation occurred through the specific activation of opiate receptors. Regulation of $165,71,62,58,55$, and $51 \mathrm{kDa}$ by chronic morphine was specific to the LC among the brain regions studied, whereas regulation of 145 and 14-20 kDa was also observed in the frontal cortex, neostriatum, and dorsal raphe.

Most of the phosphoproteins whose phosphorylation state or total amount was increased by chronic morphine treatment in the LC in vivo were also shown to have their phosphorylation state decreased by acute morphine treatment in isolated LC nuclei ex vivo. In addition, the phosphorylation state of most of these morphine-regulated phosphoproteins was stimulated by forksolin or cAMP analogs in isolated LC and by CAMP in broken cell preparations of this brain region, supporting the view that these proteins are physiological substrates for CAMP-dependent protein kinase in the LC.

Phosphoproteins regulated by morphine and CAMP were designated "MARPPs," morphine- and CAMP-regulated phosphoproteins, whereas those regulated by morphine but

\footnotetext{
Received Mar. 31, 1989; revised June 15, 1989; accepted June 17, 1989.

This research was conducted while E.J.N. was a Pfizer Scholar. This work was also supported by USPHS grant DA54093 and the Alfred P. Sloan Foundation (both to E.J.N.), and the Abraham Ribicoff Research Facilities, Connecticut Mental Health Center, State of Connecticut Department of Mental Health.

Correspondence should be addressed to Eric J. Nestler, M.D., Ph.D., Departments of Psychiatry and Pharmacology, Yale University School of Medicine and Connecticut Mental Health Center, 34 Park St., New Haven, CT 06508.

a Present address: Departament de Biologia Cellular i Anatomia Patologica, Facultat de Medicina, Hospital de Bellvitge, Universitat de Barcelona, Barcelona, Spain.

Copyright (C) 1989 Society for Neuroscience $0270-6474 / 89 / 124371-17 \$ 02.00 / 0$
}

not by cAMP were designated "MPPPs." Taken together, the results of this study indicate that chronic morphine produces specific alterations in CAMP-dependent protein phosphorylation in the LC and raise the possibility that regulation of these specific phosphoproteins contributes to the development of tolerance and/or dependence in these neurons.

Acute and chronic opiates produce profound effects on the CNS, yet the mechanisms underlying opiate action remain unknown. One system that has been used to study opiate action in brain is the locus coeruleus (LC). The $\mathrm{LC}$ is a relatively homogeneous brain-stem nucleus located in the anterior pons (Foote et al., 1983). It contains the cell bodies of more than half of all of the noradrenergic neurons in the brain and provides over $90 \%$ of the noradrenergic innervation of the cerebral cortex. Acutely, opiates decrease the firing rate of LC neurons apparently through the regulation of 2 types of ion channels: increased conductance of a $\mathrm{K}^{+}$channel plus decreased conductance of a slowly depolarizing $\mathrm{Na}^{+}$channel (North and Williams, 1985; Aghajanian and Wang, 1987; North et al., 1987; Wang and Aghajanian, 1987). Regulation of both channels is mediated through pertussis toxin-inhibitable G-proteins (Aghajanian and Wang, 1986; North et al., 1987), whereas only regulation of the depolarizing channel appears to be mediated through decreased neuronal levels of cAMP (Andrade and Aghajanian, 1985; Wang and Aghajanian, 1987). Chronically, LC neurons develop tolerance to opiates, in that their firing rate returns toward normal levels after continued opiate exposure (Aghajanian, 1978; Christie et al., 1987), and develop dependence on opiates, in that their firing rate increases several fold higher than control levels upon abrupt cessation of opiate treatment in vivo (Aghajanian, 1978; Beitner et al., 1989). Such changes in the excitability of LC neurons appear to play an important role in mediating the acute and chronic effects of opiates in whole animals, including humans (see Redmond and Krystal, 1984; Grant et al., 1988).

The biochemical basis underlying the electrophysiological changes in LC neurons in response to chronic opiate treatment does not appear to be accounted for by changes in opiate receptors or ion channels per se (see Redmond and Krystal, 1984; Christie et al., 1987; Loh et al., 1988), indicating the possible involvement of intracellular mechanisms, perhaps those involving G-proteins and cAMP, in these phenomena. Indeed, recent studies have shown that chronic morphine treatment upregulates the cAMP system in the LC at several levels. Such treatment increases levels of pertussis toxin-sensitive G-proteins $\left(G_{i \alpha}\right.$ and $\left.G_{o \alpha}\right)$ (Nestler et al., 1989), adenylate cyclase ac- 
tivity (Duman et al., 1988), and cAMP-dependent protein kinase activity (Nestler and Tallman, 1988). As cAMP and agents that increase cAMP levels are known to activate LC neurons (North et al., 1987; Wang and Aghajanian, 1987), this up-regulation of the cAMP system, which is specific to the LC among the brain regions studied, would be expected to increase the excitability of LC neurons and could thereby contribute to the development of opiate tolerance, dependence, and/or withdrawal.

In the present study, we investigated whether chronic morphine treatment also produces alterations in the LC at the next step in the cAMP system: namely, specific phosphoproteins that are substrates for CAMP-dependent protein kinase. There is now impressive evidence that protein phosphorylation is a fundamental regulatory mechanism in the nervous system and that brain phosphoproteins are involved in the regulation of diverse aspects of neuronal function (see Nestler and Greengard, 1984, 1989; Gispen and Routtenberg, 1986; Schwartz and Greenberg, 1987). Identification and characterization of specific phosphoproteins altered by morphine in the LC and other brain regions are, therefore, critical steps in understanding the biochemical basis of morphine action in the nervous system.

We show here that chronic morphine alters the phosphorylation states or total amounts of a number of phosphoproteins and that most of these changes are specific to the LC among the brain regions studied. In addition, we demonstrate that most of the phosphoproteins regulated by chronic morphine in vivo are also regulated with respect to their state of phosphorylation by acute morphine in isolated, intact LC nuclei ex vivo. We also show that most of these phosphoproteins are endogenous substrates for cAMP-dependent protein kinasc in intact and broken cell preparations of the LC. Taken together, the results demonstrate that chronic morphine produces changes in specific substrates for CAMP-dependent protein kinase and suggest that such changes in protein phosphorylation could play a role in the development and expression of morphine addiction in these neurons.

\section{Materials and Methods}

In vivo drug treatments. Male Sprague-Dawley rats (initial weight 150 $200 \mathrm{gm}$ ) were used in these studies. Morphine pellets (National Institute on Drug Abuse, Rockville, MD), containing $75 \mathrm{mg}$ of morphine base, were implanted subcutaneously in rats under light halothane anesthesia at a rate of 1 pellet/d for $5 \mathrm{~d}$ and were used on day 6 . Such morphine treatment has been shown to produce states of tolerance and dependence in rats based on behavioral criteria (Blasig et al., 1973) and in individual LC neurons based on electrophysiological studies (Aghajanian, 1978). Equivalent states of tolerance and dependence were confirmed in the rats used in this study by demonstrating: (1) tolerance to the analgesic effects of a single acute morphine dose $(20 \mathrm{mg} / \mathrm{kg}$; morphine sulfate, National Institute on Drug Abuse); (2) behavioral withdrawal in response to acute naltrexone $(10 \mathrm{mg} / \mathrm{kg}$; Dupont); and (3) tolerance, dependence, and withdrawal in individual LC neurons in electrophysiological studies (see Beitner et al., 1989). In some experiments, rats received only a single morphine pellet and were used the next day; this short-term treatment results in comparatively very low levels of tolerance and dependence (Blasig et al., 1973; Aghajanian, 1978). Control animals either underwent identical anesthesia and surgery with the implantation of placebo pellets (obtained from the National Institute on Drug Abuse) or underwent no treatment; these 2 types of controls did not yield different results.

Rats were treated concomitantly with naltrexone and morphine as follows (Nestler et al., 1989): 1 morphine pellet/d as above plus daily subcutaneous injections of $50 \mathrm{mg} / \mathrm{kg}$ of naltrexone in a $0.5 \mathrm{ml}$ emulsion of light mineral oil : mannide monooleate (Sigma) : saline (1:1:1) plus daily intraperitoneal injections of $50 \mathrm{mg} / \mathrm{kg}$ of naltrexone in saline.
These treatment conditions were shown to block the development of tolerance and dependence in rats by behavioral means and in LC neurons by electrophysiological means.

Isolation and incubation of LC nuclei ex vivo. The $2 \mathrm{LC}$ nuclei isolated from a single rat (see below) were pooled and maintained in "physiological buffer" (in mM: $126 \mathrm{NaCl}, 5 \mathrm{KCl}, 1.25 \mathrm{NaH}_{2} \mathrm{PO}_{4}, 25$ Tris, 2 $\mathrm{CaCl}_{2}, 2 \mathrm{MgCl}_{2}, 20 \mathrm{D}$-glucose, $\mathrm{pH} 7.4$ ) at $30^{\circ} \mathrm{C}$ with continuous oxygenation. Pairs of LC nuclei were first preincubated for $45 \mathrm{~min}$ with one change of medium, after which time the medium was changed and the nuclei were incubated for 10-20 $\mathrm{min}$ in the presence or absence of various drugs: $100 \mu \mathrm{M}$ morphine sulfate, $10-100 \mu \mathrm{M}$ forskolin (Sigma), and/or $100 \mu \mathrm{M}$ naloxone (Sigma). These doses were chosen because they have been shown previously to produce maximal regulation of adenylate cyclase activity in the LC (Duman et al., 1988). This method of acute in vitro morphine treatment was used because, in preliminary studies, acute in vivo administration of morphine to rats did not result in consistent changes in protein phosphorylation in the LC. This is probably due to postmortem changes that obscure the effects of acute morphine.

Preparation of tissue extracts. Brains were removed rapidly from decapitated rats and cooled immediately in ice-cold physiological buffer. Coronal scctions, $0.7 \mathrm{~mm}$ thick, at the level of the LC or dorsal raphe were obtained by use of a McIlwain tissue slicer. LC and dorsal raphe nuclei were excised from coronal sections by using a 15-gauge syringe needle to "punch out" individual nuclei as described (Nestler and Tallman, 1988). Larger brain regions, namely frontal cortex and neostriatum (caudate putamen), were obtained by gross dissection.

Isolated brain regions were homogenized in different buffers depending on their subsequent use. In some experiments, brain regions were homogenized (10 $\mathrm{mg}$ of tissue/ $\mathrm{ml})$ in ice-cold "Tris buffer" $(10 \mathrm{mM}$ Tris pH 7.4, 2 mM EDTA, $1 \mathrm{~mm}$ dithiothreitol, 50 kallikrein units $/ \mathrm{ml}$ aprotinin, $10 \mu \mathrm{g} / \mathrm{ml}$ leupeptin) and incubated at $4^{\circ} \mathrm{C}$ for $5 \mathrm{~min}$. Aliquots of the samples were then adjusted by the addition of a 10 -fold concentrated solution to contain (final concentrations): $20 \mathrm{~mm}$ citric acid, $0.01 \%$ nonidet $\mathrm{P}-40$ with a final $\mathrm{pH}$ of $2.8-3.0$. In other experiments, brain rcgions were homogenized directly in $20 \mathrm{~mm}$ citric acid, $0.01 \%$ nonidet $\mathrm{P}-40$ with a final $\mathrm{pH}$ of $2.8-3.0$. The acidified homogenates were centrifuged at $10,000 \times g$ in a Savant microfuge for $15 \mathrm{~min}$ at $4^{\circ} \mathrm{C}$. The pellets were discarded and the supernatants ("acid extracts") were neutralized by the addition of $200 \mu \mathrm{l} / \mathrm{ml}$ of $200 \mathrm{mM} \mathrm{Na} \mathrm{HPO}_{4}$.

This procedure for the preparation of acid extracts of nervous tissue is similar to that used previously (Forn and Greengard, 1978; Nestler and Greengard, 1980; Dolphin and Greengard, 1981) with the following modifications. Nonidet P-40 was included with the citric acid to increase the yield of cellular proteins in the final extracts. In addition, in the earlier procedures, tissue was first homogenized in the presence of $\mathrm{Zn}^{2+}$ (which inhibits endogenous protein kinases and protein phosphatases during homogenization) and $\mathrm{Zn}^{2+}$ pellets were then homogenized in citric acid; this procedure therefore permits back-phosphorylation analysis only of $\mathrm{Zn}^{2+}$-precipitable proteins. We have omitted the $\mathrm{Zn}^{2+}$ step and homogenized tissue directly in the acidic buffer to enable analysis of all acid/nonidet P-40-soluble proteins. The validity of the revised procedure was indicated by the following experiments. First, cAMPinduced changes in synapsin I phosphorylation in intact brain tissue were similar as determined by the 2 methods (see Table 2). Second, incubation of neutralized acid extracts prepared according to our procedure in the presence of $\left[\gamma^{-32} \mathrm{P}\right] \mathrm{ATP}$ for $30 \mathrm{~min}$ resulted in virtually no incorporation of phosphate into tissue proteins, indicating that protein kinase activities are irreversibly inactivated by this procedure. Third, incubation of ${ }^{32} \mathrm{P}$-back-phosphorylated neutralized acid extracts (see below) in the presence of nonradioactively-labeled ATP for $30 \mathrm{~min}$ resulted in virtually no decrease in ${ }^{32} \mathrm{P}$-labeling of tissue proteins, indicating that protein phosphatase activities are also irreversibly inactivated by this procedure.

Back-phosphorylation assays. Levels of protein phosphorylation in neutralized acid extracts were analyzed by back phosphorylation according to published procedures (Forn and Greengard, 1978; Nestler and Greengard, 1980; Dolphin and Greengard, 1981). Indirect back phosphorylation involved analysis of tissue extracts derived from brain regions homogenized in Tris buffer prior to acidification. Direct back phosphorylation involved analysis of tissue extracts derived from brain samples homogenized directly in the acid medium. For both types of back-phosphorylation assays, duplicate aliquots of extracts (containing $10-20 \mu \mathrm{g}$ of protein) were incubated for $30 \mathrm{~min}$ at $30^{\circ} \mathrm{C}$ in a final volume of $70 \mu \mathrm{l}$ in phosphorylation assay buffer (final concentrations): $50 \mathrm{mM}$ Tris pH 7.4, $10 \mathrm{~mm} \mathrm{MgCl}_{2}, 1 \mathrm{~mm}$ EDTA, 1 mM EGTA, 0.05\% nonidet 
P-40, $10 \mathrm{~mm}$ dithiothreitol, $0.3 \mu \mathrm{g} /$ tube purified catalytic subunit of cAMP-dependent protein kinase (Sigma), and $10 \mu \mathrm{M}\left[\gamma^{-32} \mathrm{P}\right] \mathrm{ATP}(30 \mathrm{Ci} /$ mmol; New England Nuclear). The reactions were initiated by the addition of the ATP and were terminated as described below. Nonidet P-40 and dithiothreitol were included in the phosphorylation reaction, as they have been shown to be necessary for maximal levels of protein phosphorylation in the LC and some other tissues (Nestler and Greengard, 1982; Nestler and Tallman, 1988). Levels of back phosphorylation of individual phosphoproteins analyzed by this procedure were linear over a 3-fold range of tissue concentration. At a given tissue concentration, levels of back phosphorylation of individual phosphoproteins analyzed in this study under the assay conditions used were near maximal levels: they were at least $\sim 80 \%$ of phosphorylation levels seen with longer incubation times, higher concentrations of ATP, and/or higher concentrations of protein kinase.

One- and 2-dimensional electrophoresis. For 1-dimensional electrophoresis, phosphorylation reactions were terminated by the addition of $30 \mu \mathrm{l}$ of "SDS-stop solution" (final concentrations: Tris $50 \mathrm{~mm}$ pH 6.7, $4 \%$ glycerol, $2 \%$ SDS, $2 \%$ 2-mercaptoethanol, with bromophenol blue as a marker), and the samples were boiled for $2 \mathrm{~min}$. The samples were then subjected to 1-dimensional SDS-polyacrylamide gel electrophoresis (Laemmli, 1970), usually with a final acrylamide concentration of $7.5 \%$ in the resolving gels. The ratio of acrylamide to bisacrylamide in all experiments was 25:1. The molecular weights of proteins of interest were determined by use of protein standards (Sigma).

For 2-dimensional electrophoresis, phosphorylation reactions were terminated by the addition of $40 \mathrm{mg}$ of crystalline urea plus $7 \mu \mathrm{l}$ of isoelectric focusing (IEF)-stop solution [final concentrations: $2 \%$ nonidet P-40, 2\% ampholines pH 3-10 (Biorad), 5\% 2-mercaptoethanol]. In some experiments, phosphorylation reactions were terminated by the addition of $1 \%$ SDS, and the mixtures were then adjusted with IEFstop solution as above, except that the final concentration of nonidet P-40 was $4 \%$ and that of SDS was $0.5 \%$. The inclusion of the SDS, which aids in the solubilization of some particulate proteins and thereby in their penetration into $\mathrm{pH}$ gradient gels, did not alter the resolution of the proteins analyzed in the present study; as a result, most of the experiments reported here utilized IEF-stop solution without SDS. The samples were subjected to IEF in tube gels according to published procedures (O'Farrell, 1975). Briefly, tube gels ( $2 \mathrm{~mm}$ ID) contained: $9 \mathrm{M}$ urea, $4 \%$ acrylamide (ratio of acrylamide to bisacrylamide was $25: 1$ ), $2 \%$ nonidet $\mathrm{P}-40,4 \%$ ampholines (ratio of $\mathrm{pH} 3-10$ to $\mathrm{pH} 5-7$ was $1: 1$ ). The tube gels were electrophoresed at $400 \mathrm{~V}$ overnight. The resulting tube gels were then equilibrated in $2 \mathrm{ml}$ of SDS-stop solution for $10-$ $15 \mathrm{~min}$ at room temperature and layered on top of SDS-polyacrylamide gels and subjected to electrophoresis in the second dimension. The electrophoresis conditions used resolved proteins with isoelectric points between 4.5 and 7.5 based on isoelectric point standards (BDH, London, $\mathrm{UK}$ ) and on the $\mathrm{pH}$ of the tube gels measured directly by homogenizing $0.5 \mathrm{~cm}$ sections of the tube gels in water and determining their $\mathrm{pH}$ with a pH meter.

Resulting 1- and 2-dimensional gels were dried, and phosphorylated proteins were detected by autoradiography with or without intensifying screens (Dupont). The amount of ${ }^{32} \mathrm{P}$ incorporated into individual bands was determined by cutting bands out of dried gels and quantitating the radioactivity contained therein by liquid scintillation spectrometry. Alternatively, densitometry was used to quantitate levels of ${ }^{32} \mathrm{P}$ incorporation. Phosphorylation data obtained from frontal cortex and neostriatum were normalized for protein content according to the method of Lowry et al. (1951). Phosphorylation data obtained from LC and dorsal raphe were normalized "per punch," since punches of these nuclei werc found to contain reproducible amounts of protein (about $75 \mu \mathrm{g}$ of protein per LC pair and per single dorsal raphe nucleus). Levels of phosphorylation of individual phosphoproteins in this paper are expressed as a percentage of control levels. Overall patterns of protein phosphorylation showed remarkable consistency from rat to rat and from day to day; however; certain individual phosphoproteins showed some variability. Much of this variability appeared to reside in the 2-dimensional electrophoresis per se, and not in the dissections, since these minor variabilities were just as common between duplicates of the same brain sample as between different brain samples. Therefore, for a given day's experiments, at least 2 rats for each condition (e.g., 2 control rats and 2 morphine-treated rats) were used, and each brain sample from each of these rats was analyzed in duplicate (including duplicate 2-dimensional gels). This protocol resulted in reproducible and consistent measures of protein phosphorylation.
Endogenous and back phosphorylation of crude subcellular fractions of $L C$. In some experiments, $L C$ nuclei were homogenized $(10 \mathrm{mg} / \mathrm{ml})$ in the Tris buffer mentioned above and centrifuged at $150,000 \times g$ for 10 min at $4^{\circ} \mathrm{C}$ in a Beckman airfuge. The resulting supernatant was designated the soluble fraction. The resulting pellet was resuspended in the original volume of the same buffer and designated the particulate fraction. Aliquots of soluble and particulate fractions (containing 20 $40 \mu \mathrm{g}$ of protein) were then analyzed by endogenous phosphorylation (Walaas et al., 1983) exactly as described previously (Nestler and Tallman, 1988). Endogenous phosphorylation was carried out in the absence or presence of $5 \mu \mathrm{M} 8$-bromo-cAMP or $5 \mu \mathrm{g} /$ tube of protein kinase inhibitor (a specific inhibitor of cAMP-dependent protein kinase, Sigma). All of the changes in protein phosphorylation induced by CAMP in LC fractions were reversed completely by coincubation with the protein kinase inhibitor (data not shown). In the same experiments, other aliquots of each fraction (containing 10-20 $\mu \mathrm{g}$ of protein) were adjusted to contain $20 \mathrm{~mm}$ citric acid, $0.01 \%$ nonidet $P-40$ and centrifuged at $10,000 \times g$ for $15 \mathrm{~min}$. The acid extracts of each fraction were neutralized with $200 \mathrm{mM} \mathrm{Na} \mathrm{HPO}_{4}(200 \mu \mathrm{l} / \mathrm{ml})$ and then back phosphorylated as described above. Endogenous- and back-phosphorylated samples were then subjected to 1- or 2-dimensional electrophoresis.

Exact comigration of proteins detected in different subcellular fractions or by different phosphorylation assays was confirmed in 2 ways. First, within the same experiment, mixtures of back- and endogenousphosphorylated LC extracts, as well as each alone, were analyzed in the same 2-dimensional gels. Similarly, mixtures of soluble and particulate fractions were analyzed in the same 2-dimensional gels. As expected, mixtures of the 2 fractions were indistinguishable from analyses of the whole LC. Second, in some experiments, molecular weight standard proteins were included with the various samples, and the resulting 2 -dimensional gels were stained by Coomassie blue. The stained bands of molecular weight standards then permitted exact overlay of the resulting gels and autoradiograms.

One-dimensional peptide mapping of morphine-regulated phosphoproteins. Identity between phosphoproteins identified by back and endogenous phosphorylation, and in particulate and soluble fractions, was studied by 1 -dimensional peptide mapping analysis as described (Cleveland et al., 1977). Briefly, bands of individual phosphoproteins were excised from dried 2-dimensional gels and reswelled in $20 \mathrm{~mm}$ Tris pH $6.7,0.1 \%$ SDS for $10 \mathrm{~min}$ at room temperature. The gel bands were then loaded onto standard 1-dimensional SDS-polyacrylamide gels except that the stacking gels were $4 \mathrm{~cm}$ long, and the resolving gels contained $15 \%$ acrylamide. Staphylococcus aureus V-8 protease (Miles) was then loaded on top of the bands and the gels were electrophoresed at $60 \mathrm{~V}$ overnight. Resulting gels were dried and autoradiographed. Different concentrations (1-5 $\mu \mathrm{g}$ per lane) of the protease were tried for the various proteins of interest; it was found that $2.5 \mu \mathrm{g}$ produced phosphopeptide maps with the greatest resolution and this amount was used in subsequent studies.

\section{Results}

\section{Regulation of protein phosphorylation by chronic} morphine in the $L C$

In a previous study, it was found that chronic morphine produced an overall increase in cAMP-stimulated protein phosphorylation in the LC, an effect presumably due to increased levels of cAMP-dependent protein kinase activity known to occur specifically in this brain region in response to chronic morphine (Nestler and Tallman, 1988). This increase in protein kinase activity makes it virtually impossible to study the phosphorylation of specific phosphoproteins in the LC by endogenous-phosphorylation assays, as these assays cannot distinguish changes in protein phosphorylation that are due to alterations in individual phosphoproteins from those due to alterations in protein kinase or protein phosphatase activities present in the tissue extracts (see Nestler and Greengard, 1984). In order to overcome these limitations with endogenous-phosphorylation assays, back phosphorylation was used in the present study.

Back phosphorylation involves the phosphorylation by purified, exogenous cAMP-dependent protein kinase of proteins in 
Figure 1. Autoradiograms of 1-dimensional gels illustrating chronic morphine regulation of the direct back phosphorylation of $14-20 \mathrm{kDa}$ in the $\mathrm{LC}$ and other regions of rat brain. Rats were treated with morphine for $5 \mathrm{~d}$ and used on day 6 . Isolated brain regions from control and morphine-treated rats were then subjected to direct back phosphorylation with purified cAMP-dependent protein kinase and $\left[\gamma-{ }^{32} \mathrm{P}\right] \mathrm{ATP}$ and to 1-dimensional SDS-polyacrylamide gel electrophoresis (with $10 \%$ acrylamide) as described in Materials and Methods. Resulting gels were dried and autoradiographed. The arrows indicate the positions of $20,17-18$, and $14 \mathrm{kDa}$ proteins that show decreased levels of back phosphorylation in all of the brain regions studied, which, in addition to the $L C$, included the frontal cortex $(F C)$, neostriatum $(N S)$, and dorsal raphe $(D R)$.
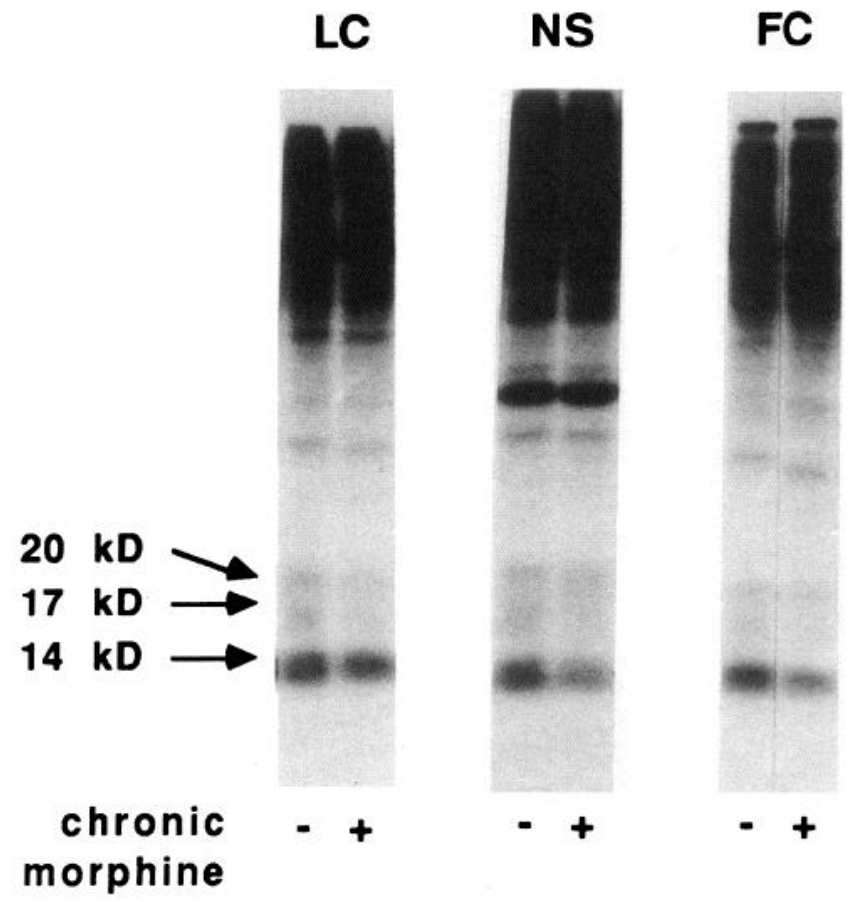

tissue extracts in which endogenous protein kinases and protein phosphatases are inactivated by prior acid treatment (see Nestler and Greengard, 1984). Back phosphorylation has been shown in a number of previous studies to enable the reproducible quantitation of the phosphorylation levels of a number of known phosphoproteins. Two types of back phosphorylation assays were used in the present study (see Materials and Methods): direct back phosphorylation, which provides an indication of the state of phosphorylation of phosphoproteins, and indirect back phosphorylation, which provides an indication of the total amount of phosphoproteins. By use of both assays, it is possible to derive information concerning the phosphorylation state and total amount of individual phosphoproteins (see Discussion).

In one series of experiments, LC nuclei from control and chronic morphine-treated rats were analyzed by direct back phosphorylation and 1-dimensional electrophoresis. It was found that chronic morphine decreased direct back-phosphorylation levels of a series of proteins of $14,17-18$, and $20 \mathrm{kDa}$ (Fig. 1).

Table 1. Regulation of back phosphorylation by chronic morphine in the locus coeruleus

\begin{tabular}{|c|c|c|c|c|c|}
\hline & \multicolumn{3}{|c|}{$\begin{array}{l}\text { A. Direct back phosphorylation } \\
{[\% \text { control } \pm \text { SEM }(\mathrm{N})]}\end{array}$} & \multicolumn{2}{|c|}{$\begin{array}{l}\text { B. Indirect } \\
{[\% \text { control } \pm \text { SEM }(\mathrm{N})]}\end{array}$} \\
\hline & $\begin{array}{l}\text { 1. Chronic } \\
\text { morphine } \\
\text { (5 days) }\end{array}$ & $\begin{array}{l}\text { 2. Chronic } \\
\text { morphine }+ \\
\text { naltrexone }\end{array}$ & $\begin{array}{l}\text { 3. Short-term } \\
\text { morphine } \\
\text { (1 day) }\end{array}$ & $\begin{array}{l}\text { 1. Chronic } \\
\text { morphine } \\
\text { ( } 5 \text { days) }\end{array}$ & $\begin{array}{l}\text { 2. Chronic } \\
\text { morphine + } \\
\text { naltrexone }\end{array}$ \\
\hline MARPP-165 & $73 \pm 4(6)^{a}$ & $102 \pm 4(3)$ & $94 \pm 8$ & $104 \pm 8$ & \\
\hline MARPP-145 & $182 \pm 9(6)^{a}$ & $107 \pm 5(3)$ & $93 \pm 6$ & $172 \pm 11(6)^{a}$ & $109 \pm 8(3)$ \\
\hline MARPP-71 & $95 \pm 7(6)$ & & & $129 \pm 5(6)^{a}$ & $101 \pm 5(3)$ \\
\hline MRPP-62 & $68 \pm 9(6)^{a}$ & $98 \pm 6(3)$ & $103 \pm 7$ & $134 \pm 3(6)^{a}$ & $95 \pm 7(3)$ \\
\hline MARPP-58 & $132 \pm 6(6)^{a}$ & $107 \pm 4(3)$ & $93 \pm 10(4)$ & $127 \pm 2(6)^{a}$ & $99 \pm 8(3)$ \\
\hline MARPP-55 & $78 \pm 5(6)^{a}$ & $102 \pm 3(3)$ & $97 \pm 7$ & $96 \pm 8$ & \\
\hline MRPP-51 & $143 \pm 8(6)^{a}$ & $106 \pm 5(3)$ & $100 \pm 6$ & $136 \pm 3(6)^{a}$ & $105 \pm 9(3)$ \\
\hline MARPP-14-20 & $49 \pm 6(6)^{a}$ & $97 \pm 5(3)$ & $99 \pm 4$ & $103 \pm 7$ & \\
\hline Synapsin I & $97 \pm 4(6)$ & & & $101 \pm 4$ & \\
\hline
\end{tabular}

Rats were treated with morphine as follows: columns Al and B1, one subcutaneous morphine pellet daily for $5 \mathrm{~d}$ and rats were used on day 6 ; columns A2 and B2, one subcutaneous morphine pellet daily plus daily injections of naltrexone (see Materials and Methods) for $5 \mathrm{~d}$ and rats were used on day 6; or column A3, one subcutaneous morphine pellet and rats were used the next day. Isolated LC nuclei from control and morphine-treated rats were subjected to direct (column A) or indirect (column B) back phosphorylation and 1- or 2-dimensional gel electrophoresis as described in Materials and Methods. Individual phosphoproteins were identified by autoradiography and quantitated by liquid scintillation or densitometry. Data were calculated as percent of back phosphorylation of control samples \pm SEM. (N $=$ number of LC pairs analyzed.) Data for MARPP-14-20 and synapsin I were obtained from 1-dimensional gels (e.g., Fig. 1); data for the others from 2-dimensional gels (e.g., Fig. 2). Individual proteins are referred to as "MARPPs" or "MRPPs" as discussed in the text.

${ }^{a} p<0.05$ by $\chi^{2}$ test. 


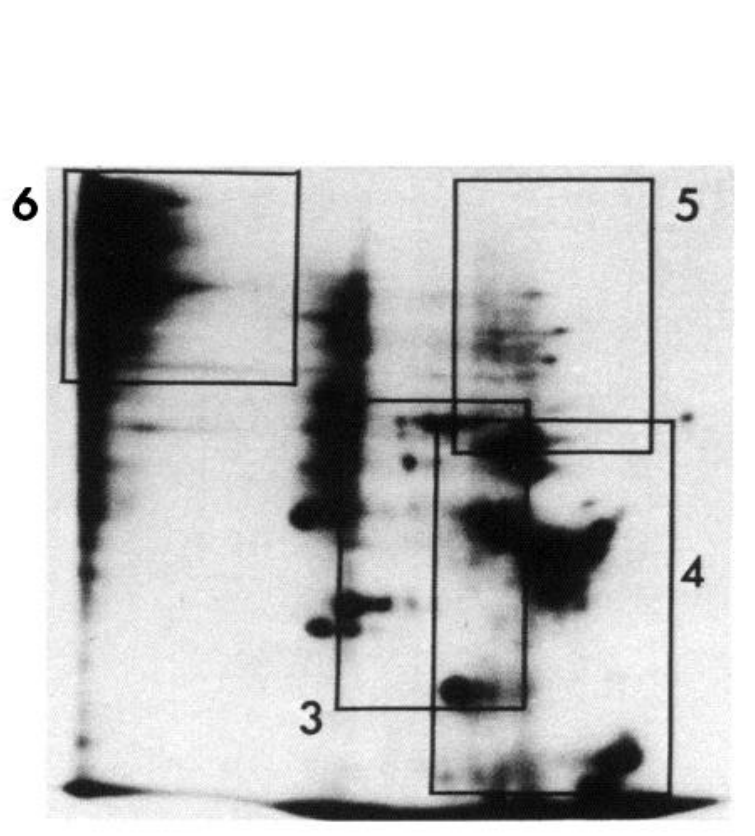

control

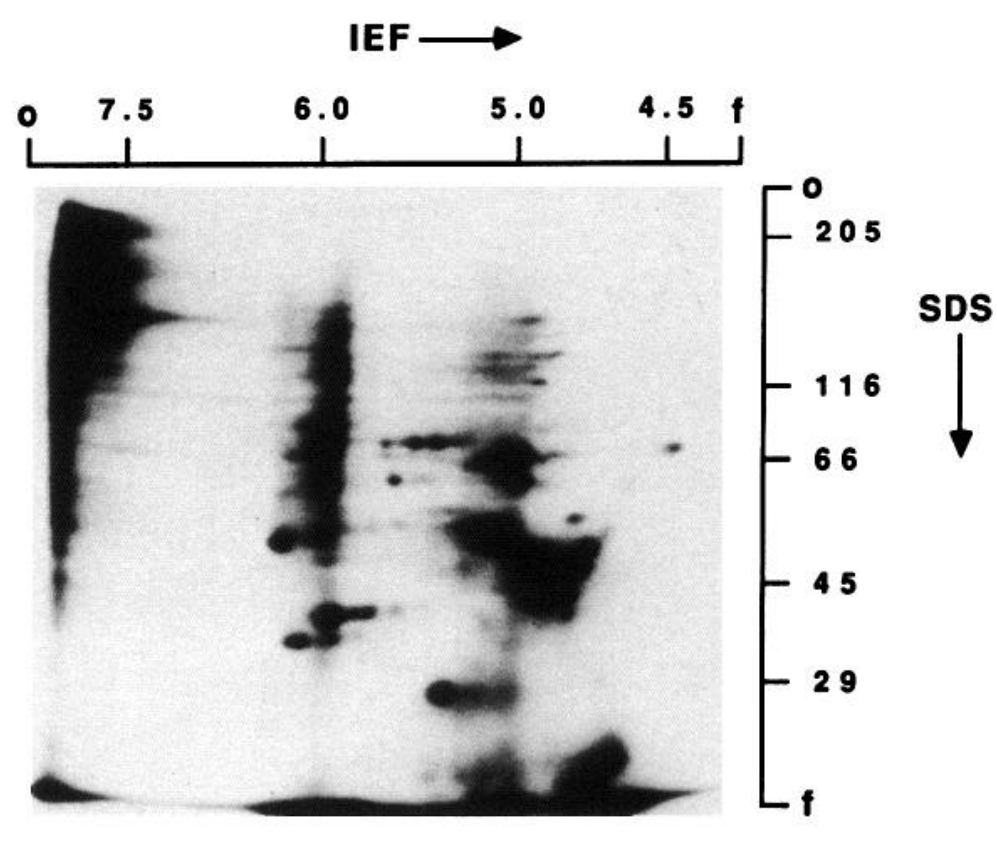

chronic morphine

Figure 2. Autoradiograms of 2-dimensional gels illustrating the effect of chronic morphine on direct back phosphorylation in the LC. Rats were treated with morphine for $5 \mathrm{~d}$ and used on day 6 . Isolated LC nuclei from control and morphine-treated rats were then subjected to direct back phosphorylation with purified cAMP-dependent protein kinase and $\left[\gamma-{ }^{32} \mathrm{P}\right] \mathrm{ATP}$ and to 2 -dimensional electrophoresis (with $7.5 \%$ acrylamide in the second dimension) as described in Materials and Methods. Resulting gels were dried and autoradiographed. Boxes numbered 3, 4, 5, and 6 drawn on the gel to the left delineate the portions of 2-dimensional gels that are shown in Figures 3, 4, 5, and 6, respectively, with greater magnification and varying exposures to maximize the visualization of proteins of interest.

These proteins are referred to collectively as $14-20 \mathrm{kDa}$ since subsequent studies demonstrated considerable similarities in their biochemical and immunochemical properties (Guitart and Nestler, 1990). Changes in other phosphoproteins were not apparent on the 1-dimensional gels.

When aliquots of the same samples were analyzed by 2-dimensional electrophoresis, changes in a number of additional individual phosphoproteins became apparent, although the overall pattern of protein phosphorylation was very similar in LC from control and morphine-treated rats (Fig. 2). Figures 36 show different portions of 2-dimensional gels from experiments similar to that shown in Figure 2; different exposures are shown in order to visualize particular phosphoproteins most effectively. The figures demonstrate that chronic morphine increased direct back-phosphorylation levels of 3 proteins: $58 \mathrm{kDa}$ (Fig. 3), $51 \mathrm{kDa}$ (Fig. 4), and $145 \mathrm{kDa}$ (Fig. 5), and decreased direct back-phosphorylation levels of 3 other proteins: $165 \mathrm{kDa}$ (Fig. 6) and $62 \mathrm{kDa}$ and $55 \mathrm{kDa}$ (Fig. 4). These various changes in direct back phosphorylation observed in response to chronic morphine on 1- and 2-dimensional gels from several experiments are shown quantitatively in Table 1 (column A1). [Note that $14-20 \mathrm{kDa}$ are not observed on the 2-dimensional gels shown in Fig. 2, because they are highly basic proteins and are not resolved on isoelectric focusing gels (Guitart and Nestler, 1990).]

In a second series of experiments, LC nuclei from control and morphine-treated rats were analyzed by indirect back phosphorylation and 1- or 2-dimensional electrophoresis. It was found that only some of the phosphoproteins altered by morphine by direct back phosphorylation were also altered by indirect back phosphorylation. Thus, increased indirect back-phosphorylation levels were observed for 145,58 , and $51 \mathrm{kDa}$, whereas no changes in indirect back phosphorylation were observed for 165 , 55 , or $14-20 \mathrm{kDa}$ (gels not shown due to space considerations). Interestingly, $62 \mathrm{kDa}$ showed increased levels of indirect back phosphorylation, whereas it had shown decreased levels by direct back phosphorylation. Indirect back phosphorylation also revealed increased levels of phosphorylation of an additional protein of $71 \mathrm{kDa}$, which showed no regulation by morphine by direct back-phosphorylation procedures (Fig. 3). Regulation of these various phosphoproteins by chronic morphine in the LC as measured by indirect back phosphorylation is shown quantitatively in Table 1 (column B1). Also shown in Table 1 is that chronic morphine did not alter direct or indirect backphosphorylation levels of synapsin I, a well-characterized and ubiquitous neuronal substrate for cAMP-dependent protein kinase (see Nestler and Greengard, 1984; 1986), in the LC.

\section{Effects of naltrexone on chronic morphine regulation of protein phosphorylation}

Concomitant treatment of rats with morphine and naltrexone, a long-acting opiate receptor antagonist, blocked the development of morphine tolerance and dependence based on behavioral and electrophysiological measures (see Materials and Methods). It was found that such treatment also blocked the ability of morphine to produce each of the changes observed in protein phosphorylation in direct (Table 1, column A2) and indirect (Table 1, column B2) back-phosphorylation experi- 
Locus

Coeruleus

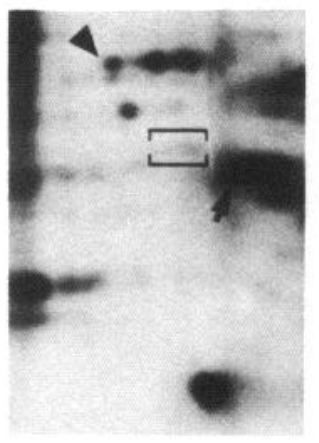

Neostriatum

\section{Frontal \\ Cortex}

Figure 3. Autoradiograms illustrating chronic morphine regulation of $58 \mathrm{kDa}$ in the LC. Isolated LC and other brain regions from control and morphinetreated rats were subjected to direct back phosphorylation and 2-dimensional gel electrophoresis as described in the legend to Figure 2. Portions of the 2-dimensional gels shown in this figure correspond to box number 3 in Figure 2 . Brackets indicate the position of a phosphoprotein of $58 \mathrm{kDa}$ whose back phosphorylation is increased by chronic morphine in the LC. This phosphoprotein was also present in the neostriatum, but not regulated by morphine in this brain region; the protein was not detectable in the frontal cortex or dorsal raphe. Arrows indicate the position of a phosphoprotein of $55 \mathrm{kDa}$, shown better in Figure 4, whose back phosphorylation is decreased by chronic morphine specifically in the LC. Arrowheads indicate the position of a phosphoprotein of $71 \mathrm{kDa}$, whose indirect, but not direct, back phosphorylation was altered by chronic morphine.
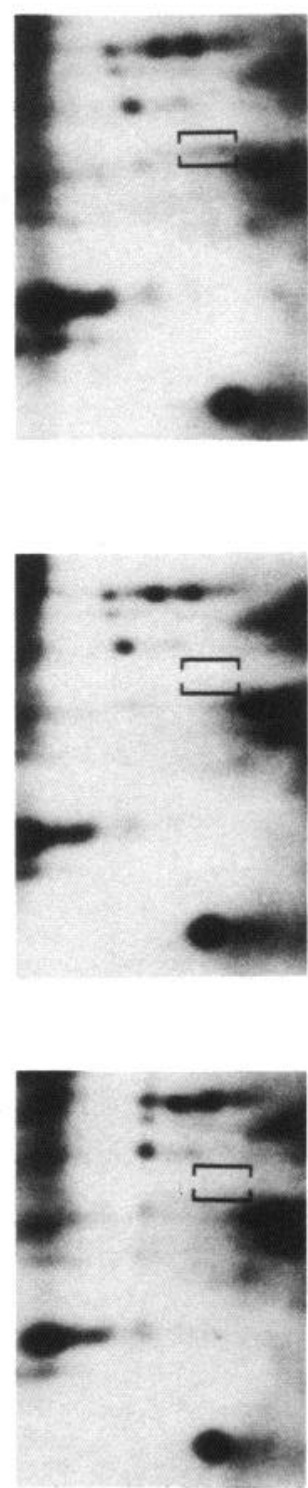

control
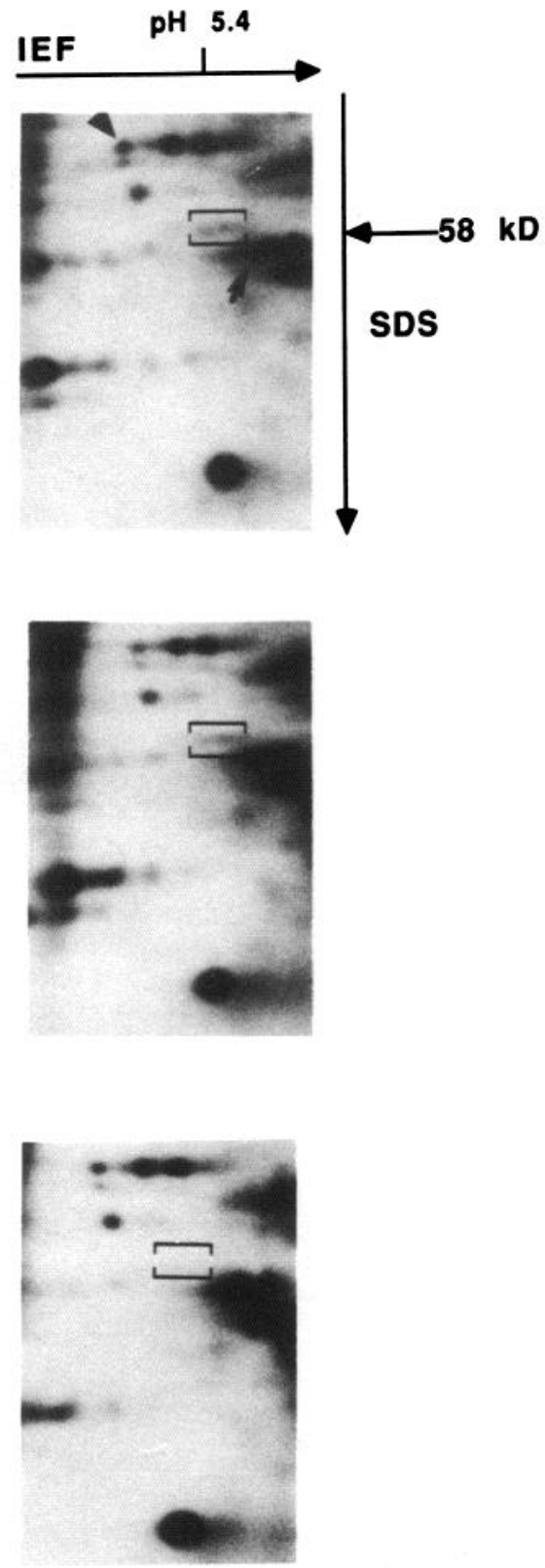

\section{Dorsal Raphe}

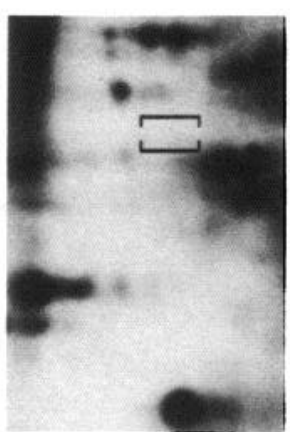



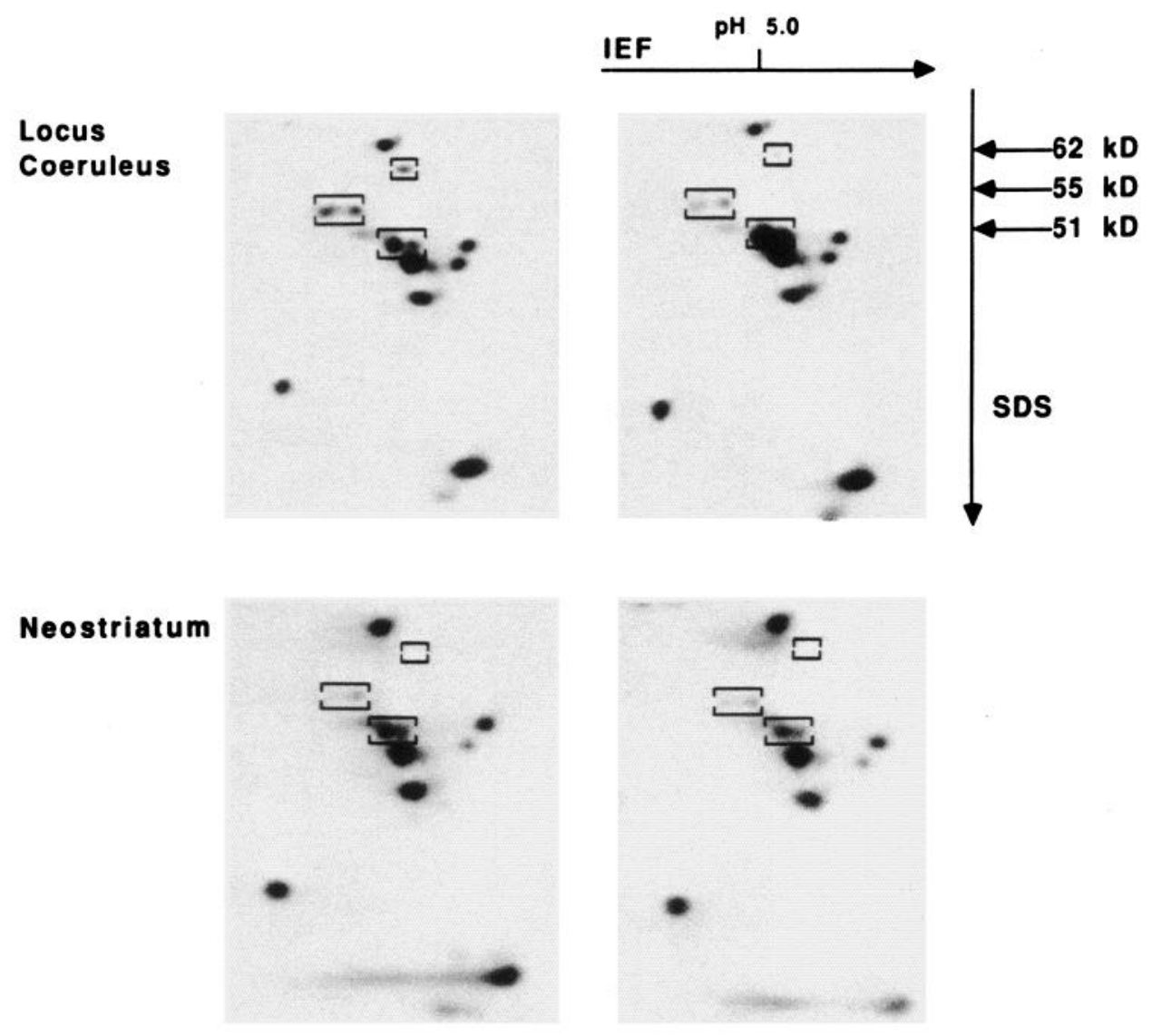

Frontal

Cortex
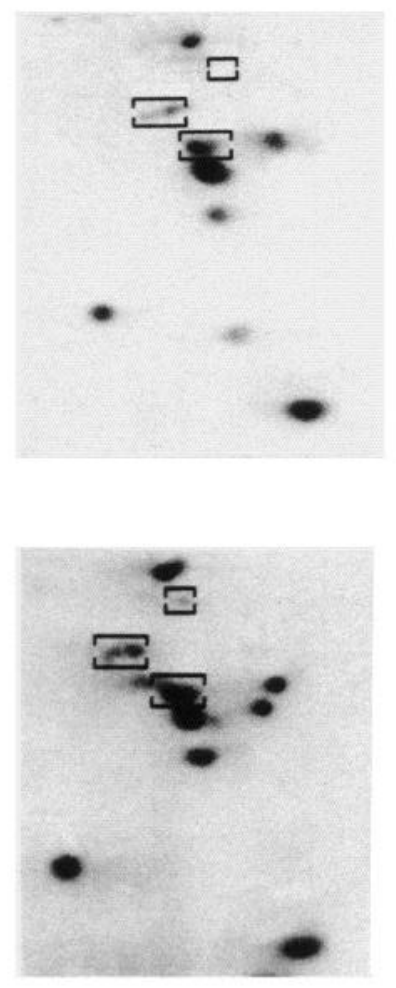

control
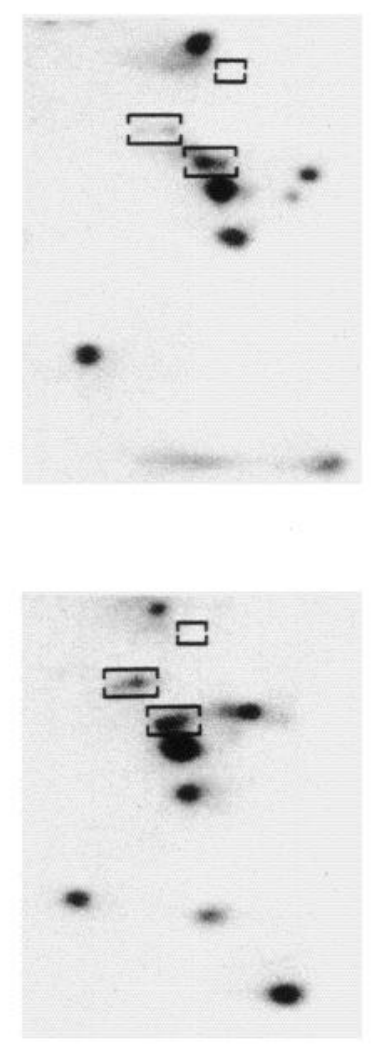

Figure 4. Autoradiograms illustrating chronic morphine regulation of 62,55 , and $51 \mathrm{kDa}$ in the LC. Isolated LC and other brain regions from control and morphine-treated rats were subjected to direct back phosphorylation and 2dimensional gel electrophoresis as described in the legend to Figure 2. Portions of the 2-dimensional gels shown in this figure correspond to box number 4 in Figure 2. Brackets indicate the positions of 3 phosphoproteins whose back phosphorylation is regulated by chronic morphine in the LC. $62 \mathrm{kDa}$ showed decreased levels of back phosphorylation in the LC; this protein was present at much lower levels in the dorsal raphe, where it was not regulated by chronic morphine and was not detectable in the neostriatum or frontal cortex. 55 and $51 \mathrm{kDa}$, respectively, showed decreased and increased levels of back phosphorylation in the LC; these proteins were present in the other brain regions at approximately similar levels, where they were not regulated by chronic morphine. 


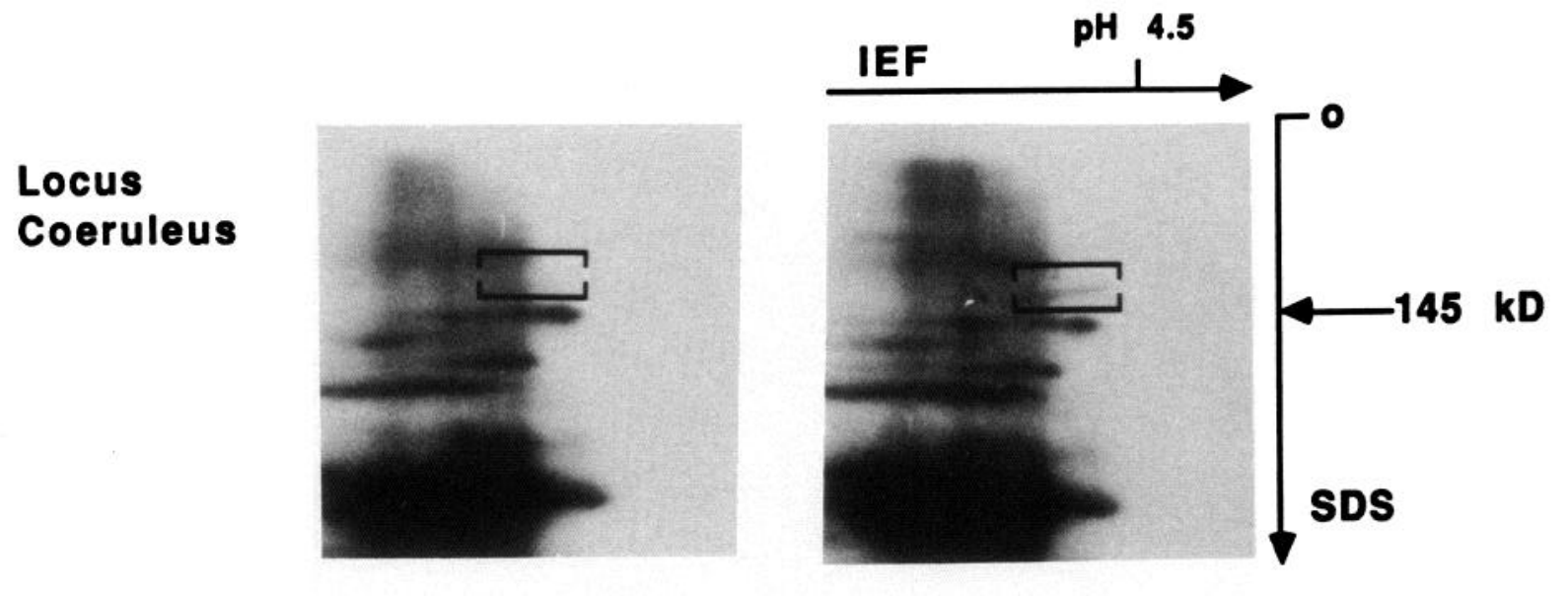

\section{Neostriatum}

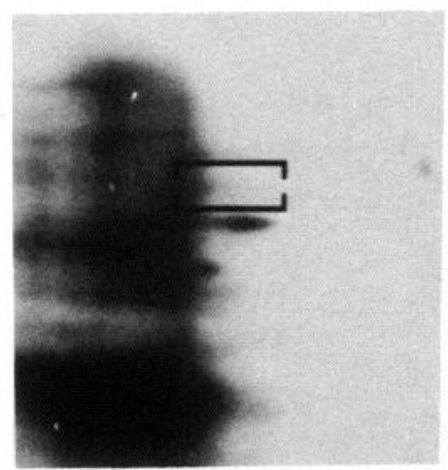

\section{Frontal \\ Cortex}

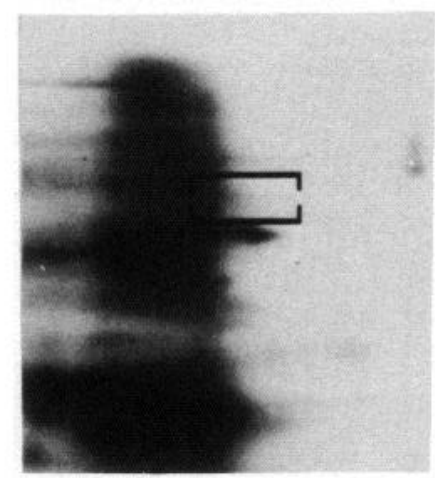

\section{Dorsal Raphe}
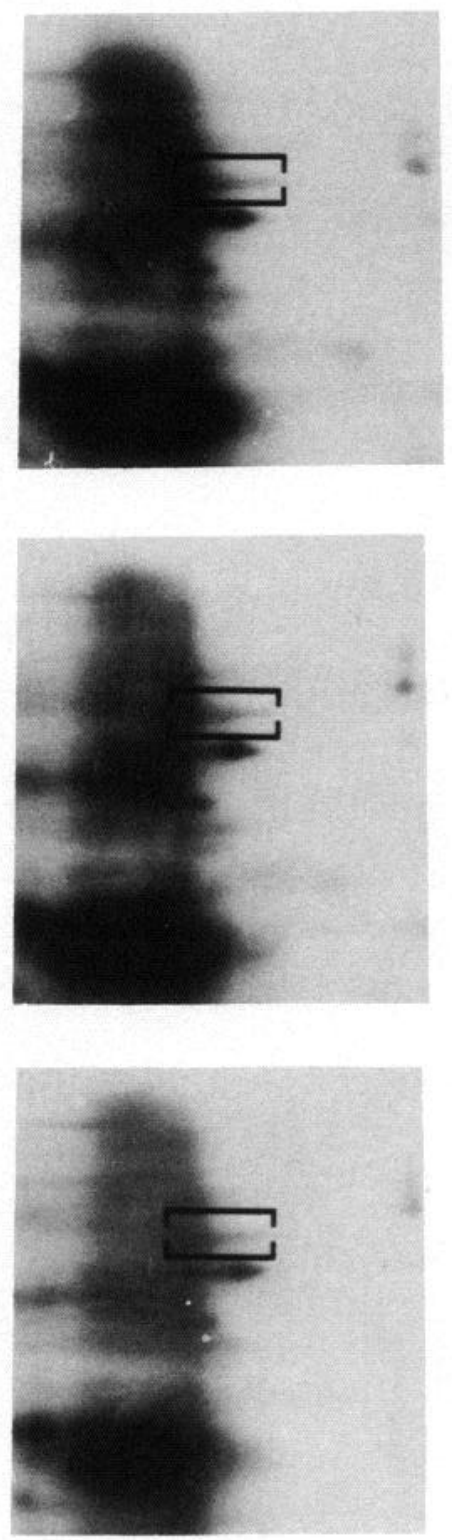

morphine

Figure 5. Autoradiograms illustrating chronic morphine regulation of $145 \mathrm{kDa}$ in the $\mathrm{LC}$ and other regions of rat brain. Isolated brain regions were subjected to direct back phosphorylation and 2-dimensional gel electrophoresis as described in the legend to Figure 2. Portions of the 2dimensional gels shown in this figure correspond to box number 5 in Figure 2. Brackets indicate the position of a phosphoprotein of $145 \mathrm{kDa}$ whose back phosphorylation is increased by chronic morphine in all of the 4 brain regions examined. Note that the autoradiograms shown in the figure are overexposed in order to reveal $145 \mathrm{kDa}$. 
Locus Coeruleus

\section{Neostriatum}

\section{Frontal Cortex}

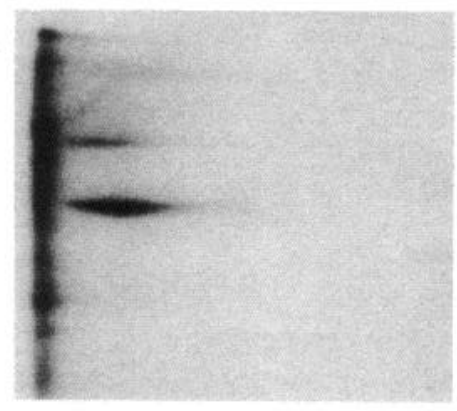

o
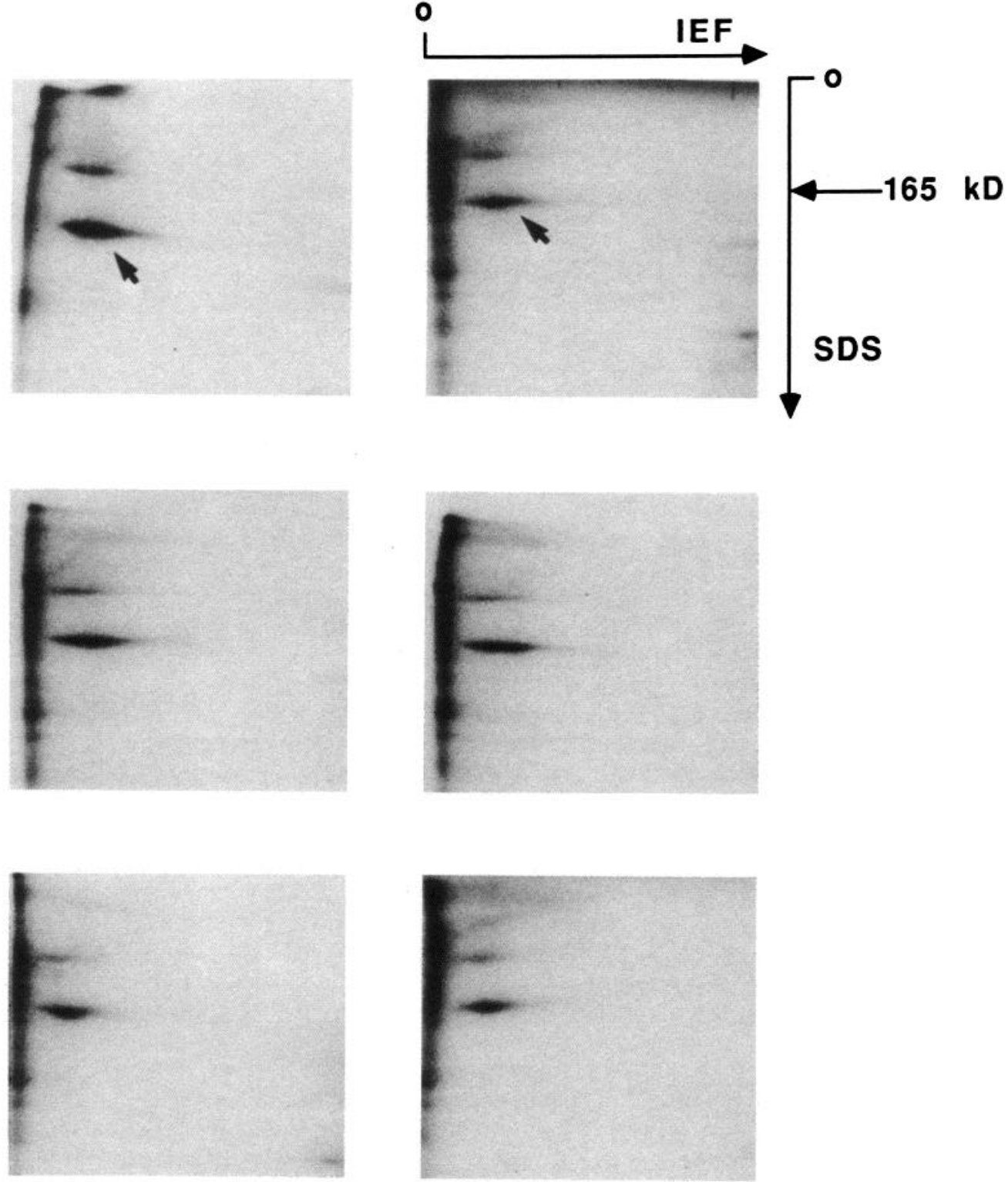

\section{Dorsal Raphe}

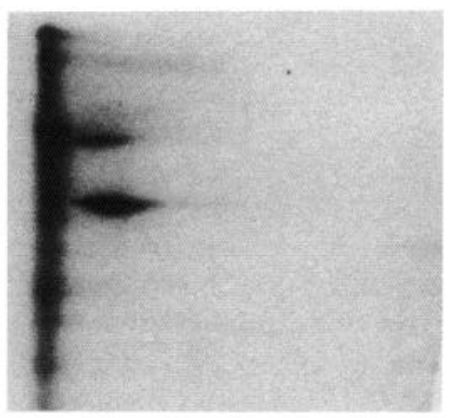

control

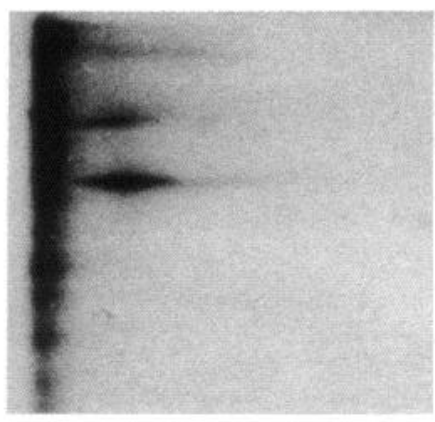

morphine

Figure 6. Autoradiograms illustrating chronic morphine regulation of $165 \mathrm{kDa}$ in the LC. Isolated LC and other brain regions from control and morphine-treated rats were subjected to direct back phosphorylation and 2-dimensional gel electrophoresis as described in the legend to Figure 2 . Portions of the resulting 2-dimensional gels shown in this figure correspond to box number 6 in Figure 2. Arrows indicate the position of a phosphoprotein of $165 \mathrm{kDa}$ whose back phosphorylation is decreased by chronic morphine in the LC. The protein is present in the other brain regions at approximately similar levels, where it shows no regulation by morphine. 
ments. The results demonstrate that morphine regulation of each of these phosphoproteins is achieved through specific actions at opiate receptors.

\section{Lack of regulation of protein phosphorylation by short-term (1 d) in vivo morphine}

It was important to determine whether chronic treatment with morphine is necessary for the various changes in protein phosphorylation (outlined above) to be observed or whether shorter periods of treatment would be equally efficacious. Therefore, rats were implanted with a single morphine pellet and were used $24 \mathrm{hr}$ later. Such treatment results in continuous exposure to morphine for $24 \mathrm{hr}$ and has been shown to produce very low levels of tolerance and dependence in rats behaviorally (Blasig et al., 1973) and in individual LC neurons electrophysiologically (Aghajanian, 1978), and to produce none of the biochemical changes in the cAMP system (i.e., G-proteins, adenylate cyclase, cAMP-dependent protein kinase) observed in response to chronic (5 d) morphine (Duman et al., 1988; Nestler and Tallman, 1988; Nestler et al., 1989). It was found that such short-term morphine treatment also failed to produce each of the changes in protein phosphorylation observed by direct back phosphorylation in response to chronic morphine (Table 1, column A3). Similarly, such treatment failed to produce changes in phosphorylation levels of $145,71,62,58$, and $51 \mathrm{kDa}$ by indirect back phosphorylation (data not shown).

\section{Regional specificity of chronic morphine regulation of protein phosphorylation}

The effect of chronic morphine on cAMP-dependent protein phosphorylation was investigated by back-phosphorylation procedures in the frontal cortex, neostriatum, and dorsal raphe in order to study the regional specificity of the changes observed in the LC. In general, there was striking consistency in patterns of back phosphorylation among the 4 brain regions studied (see Figs. 3-6). However, the various phosphoproteins regulated by chronic morphine in the LC showed different regional characteristics with respect to (1) their presence in different brain regions in control rats and (2) their regulation by morphine in those different regions. Thus, $58 \mathrm{kDa}$ (Fig. 3) was present in the LC and neostriatum, barely detectable in the frontal cortex and dorsal raphe, and regulated by morphine in the LC only. Also, $62 \mathrm{kDa}$ (Fig. 4) was present in the LC at much higher levels than in the dorsal raphe and was not detectable in the neostriatum or frontal cortex; it was regulated by morphine in the LC only. And 165 (Fig. 6), 71 (Fig. 3), and 55 and 51 kDa (Fig. 4) were detectable in all of the brain regions examined at roughly equivalent levels but were regulated by morphine in the LC only. These various changes observed only in the $\mathrm{LC}$ were also not observed in punches of pons cross sections obtained just lateral or medial to the $L C$, thereby providing further evidence for the regional specificity of these phenomena. In contrast, 145 (Fig. 5) and 14-20 kDa (Fig. 1) were detectable at similar levels, and similarly regulated by chronic morphine, in all of the brain regions examined. Prominent changes in additional phosphoproteins in the frontal cortex, neostriatum, or dorsal raphe were not observed in these studies.

\section{Regulation of protein phosphorylation by acute morphine in isolated LC nuclei}

Regulation of the above phosphoproteins by chronic morphine in the LC raised the possibility that these same proteins might also be regulated by acute morphine in this brain region. We investigated this possibility directly by determining whether acute morphine alters the phosphorylation states of these proteins in isolated, intact LC nuclei maintained ex vivo. LC nuclei were incubated in the presence or absence of morphine sulfate (100 $\mu \mathrm{M})$ for $20 \mathrm{~min}$ (see Materials and Methods) and then analyzed by direct back phosphorylation and 1- or 2-dimensional electrophoresis. It was found that, with the exception of $62 \mathrm{kDa}$, all of the phosphoproteins regulated by morphine chronically were also regulated by morphine acutely. Thus, 14-20 kDa showed increased back-phosphorylation levels as revealed with 1 -dimensional gels, and $165,145,71,58,55$, and $51 \mathrm{kDa}$ showed increased back-phosphorylation levels as revealed with 2-dimensional gels. This acute morphine regulation of protein phosphorylation is shown quantitatively in Table 2 (column Al). In contrast, acute morphine produced no change in the phosphorylation of these various proteins when analyzed by indirect back phosphorylation (Table 2, column B). In addition to the proteins mentioned above, morphine was also found to alter levels of back phosphorylation of some other phosphoproteins in some experiments, but these other changes were not as reproducible as the ones shown in Table 2 and were, therefore, not pursued further. In addition, it was found that acute morphine did not alter back-phosphorylation levels of synapsin I (Table 2).

In order to test the specificity of acute morphine regulation of protein phosphorylation in the LC, the ability of naloxone, an opiate receptor antagonist, to block morphine action was examined. It was found that incubation of $\mathrm{LC}$ nuclei with naloxone completely prevented the morphine-induced increases in the back phosphorylation of each of the individual phosphoprotcins studied above (Table 2, column A5). Naloxone by itself had no effect on protein phosphorylation (Table 2, column A4). The results indicate that acute morphine regulation of protein phosphorylation in the LC is achieved through specific actions at opiate receptors.

\section{Regulation of protein phosphorylation by acute forskolin in isolated LC nuclei}

Since protein phosphorylation was assayed in this study by use of purified cAMP-dependent protein kinase, the phosphoproteins identified could be physiological substrates for this enzyme. However, the high concentrations of the protein kinase used in back-phosphorylation assays can result in the phosphorylation of proteins that are not its physiological substrates (see Nestler and Greengard, 1984). Therefore, the effect of forskolin, which increases neuronal levels of cAMP by activating adenylate cyclase, on morphine-regulated phosphoproteins was investigated. LC nuclei were incubated in the presence of forskolin $(10-100 \mu \mathrm{M})$ under conditions known to stimulate cAMP-dependent protein phosphorylation (e.g., see Nestler and Greengard, 1982), and were then analyzed by direct back phosphorylation. It was found that forskolin decreased back-phosphorylation levels of $165,145,71,58,55$, and $14-20 \mathrm{kDa}$, but had no effect on 62 or $51 \mathrm{kDa}$ (Table 2, column A2).

Incubation of intact LC nuclei in the presence of $4 \mathrm{~mm}$ 8-bromo-cAMP for $10 \mathrm{~min}$ produced similar changes in protein phosphorylation (data not shown), consistent with the view that the forskolin-induced changes are mediated through increased levels of cAMP. As a further control, we studied the ability of forskolin to alter the phosphorylation of synapsin I. It was found that forskolin decreased back phosphorylation levels of synapsin $\mathrm{I}$, as has been demonstrated previously in many regions of the 
Table 2. Regulation of back phosphorylation by acute morphine and forskolin in the locus coeruleus

A. Direct back phosphorylation [\% control \pm SEM (N)]

\begin{tabular}{|c|c|c|c|c|c|c|}
\hline & 1. Morphine & 2. Forskolin & $\begin{array}{l}\text { 3. Morphine }+ \\
\text { forskolin }\end{array}$ & 4. Naloxone & $\begin{array}{l}\text { 5. Morphine }+ \\
\text { naloxone }\end{array}$ & $\frac{ \pm \text { SEM }(\mathrm{N})}{\text { Morphine }}$ \\
\hline MARPP-165 & $143 \pm 9(6)^{\alpha}$ & $61 \pm 9(6)^{a}$ & $96 \pm 5$ & $102 \pm 8(5)$ & $93 \pm 6$ & $94 \pm 9(5)$ \\
\hline MARPP- 145 & $150 \pm 11(4)^{a}$ & $79 \pm 5(6)^{a}$ & $95 \pm 11(6)$ & $98 \pm 3(3)$ & $96 \pm 9$ & $95 \pm 9(4)$ \\
\hline MARPP-71 & $129 \pm 6(6)^{a}$ & $78 \pm 4(6)^{a}$ & $100 \pm 5$ & $95 \pm 3(4)$ & $100 \pm 9$ & $100 \pm 8(4)$ \\
\hline MRPP- 62 & $101 \pm 5$ & $98 \pm 7(4)$ & & & & $105 \pm 6(3)$ \\
\hline MARPP-58 & $129 \pm 6(5)^{a}$ & $76 \pm 6(5)^{a}$ & $99 \pm 8$ & $98 \pm 7(3)$ & $93 \pm 12(5)$ & $102 \pm 9(5)$ \\
\hline MARPP-55 & $115 \pm 4(5)^{a}$ & $84 \pm 3(5)^{\alpha}$ & $99 \pm 4$ & $97 \pm 9(3)$ & $104 \pm 3$ & $98 \pm 7(4)$ \\
\hline MRPP-51 & $130 \pm 6(6)^{a}$ & $99 \pm 3(6)$ & $135 \pm 12(4)^{a}$ & $97 \pm 7(3)$ & $95 \pm 4$ & $108 \pm 9(5)$ \\
\hline MARPP-14-20 & $140 \pm 9(6)^{a}$ & $78 \pm 4(5)^{a}$ & $97 \pm 4$ & $96 \pm 7(4)$ & $106 \pm 4$ & $102 \pm 5(6)$ \\
\hline Synapsin I & $92 \pm 7$ & $60 \pm 5(5)^{a}$ & & & & \\
\hline
\end{tabular}

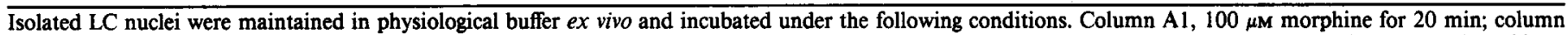

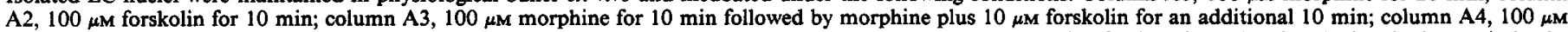

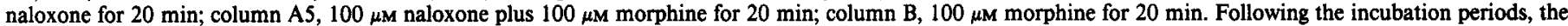

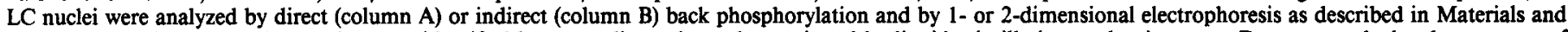

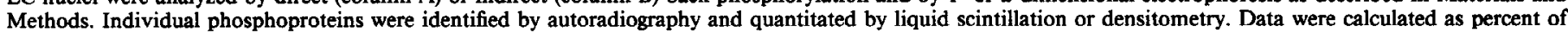

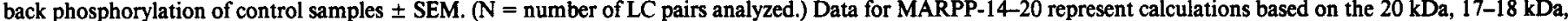

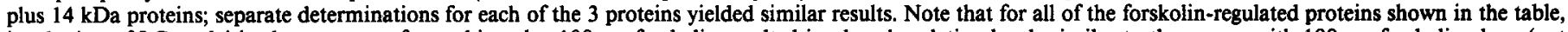

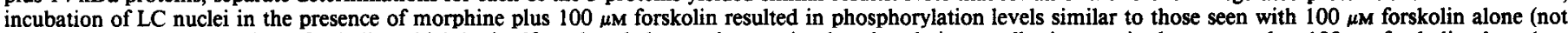

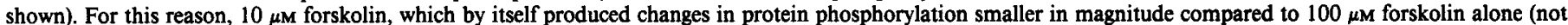
shown), was used for the morphine plus forskolin experiments.

${ }^{a} p<0.05$ by $\chi^{2}$ test.

nervous system (see Nestler and Greengard, 1984, 1986). A number of other proteins also showed decreased levels of back phosphorylation in response to forskolin, but these proteins were not altered by morphine. All of the forskolin-induced changes in protein phosphorylation were not observed when the LC were analyzed by indirect back phosphorylation (data not shown).

In order to study whether acute morphine- and forskolinregulation of protein phosphorylation in the LC involved some of the same intracellular pathways, the ability of morphine and forskolin to antagonize the effects of each other was investigated. It was found that forskolin completely reversed the actions of morphine on all of the phosphoproteins except $51 \mathrm{kDa}$. Thus, incubation of LC nuclei in the presence of $100 \mu \mathrm{M}$ morphine plus $10 \mu \mathrm{M}$ forskolin resulted in levels of direct back phosphorylation of $165,145,71,58,55$, and $14-20 \mathrm{kDa}$ that were indistinguishable from control (Table 2, column A3). In contrast, forskolin had no effect on the-ability of morphine to increase back-phosphorylation levels of $51 \mathrm{kDa}$.

\section{Identification of the morphine-regulated phosphoproteins as endogenous substrates for CAMP-dependent protein kinase}

The ability of forskolin to alter the back phosphorylation of most of the morphine-regulated phosphoproteins suggests that the proteins are endogenous substrates for cAMP-dependent protein kinase. This interpretation was studied directly by testing the ability of CAMP to stimulate the phosphorylation of the proteins by endogenous protein kinase activity in particulate or soluble fractions of the LC, and by comparing patterns of endogenous phosphorylation to those of back phosphorylation in the same subcellular fractions. It was found that the addition of cAMP stimulated the endogenous phosphorylation of 165 , $145,71,58$, and $55 \mathrm{kDa}$ (Fig. 7, gels A, B, D, and E) and 14$20 \mathrm{kDa}$ (1-dimensional gels not shown), the same proteins regulated by forskolin in intact LC nuclei (see Table 2). For some of these proteins, such as $55 \mathrm{kDa}$ (see Fig. 7, gel D), significant levels of endogenous phosphorylation were seen in the absence of cAMP. Such phosphorylation is not due to low levels of cAMP-dependent protein kinase that can be active in tissue extracts without exogenous cAMP since it was observed in the presence of protein kinase inhibitor (PKI), a specific inhibitor of this protein kinase. These proteins would appear, therefore, to be substrates for endogenous protein kinases in addition to the cAMP-dependent enzyme. In contrast, the addition of cAMP (or PKI) had no effect on the endogenous phosphorylation of $62 \mathrm{kDa}$, and the endogenous phosphorylation of $51 \mathrm{kDa}$ was not clearly detectable either in the presence or absence of cAMP (see below). Neither of these phosphoproteins were regulated by forskolin in intact LC nuclei (Table 2), raising the possibility that these proteins are primarily substrates for protein kinases other than the cAMP-dependent enzyme.

These back- and endogenous-phosphorylation experiments demonstrated that 145 and $58 \mathrm{kDa}$ were detected solely in soluble fractions (Fig. 7, gels A-C), whereas 14-20 kDa was detected solely in particulate fractions (not shown). The other morphine-regulated phosphoproteins, namely $165,71,62,55$, and $51 \mathrm{kDa}$, were roughly equally distributed between the 2 fractions (Fig. 7), although the relative distribution varied somewhat from day to day.

The identity between the back- and endogenous-phosphorylated proteins was demonstrated in 2 ways. First, for each individual phosphoprotein, exact comigration of back- and endogenous-phosphorylated proteins was shown as described in Materials and Methods. Second, individual bands were excised from 2-dimensional gels and analyzed by 1-dimensional peptide mapping. As shown in Figure 8, it was found that the patterns of phosphopeptide fragments resulting from each protein were identical between the back- and endogenous-phosphorylated samples. Moreover, for those phosphoproteins present in both the soluble and particulate fractions, identical peptide maps resulted from proteins derived from the 2 subcellular fractions (Fig. 8). [Note: the identity between back- and endogenous- 

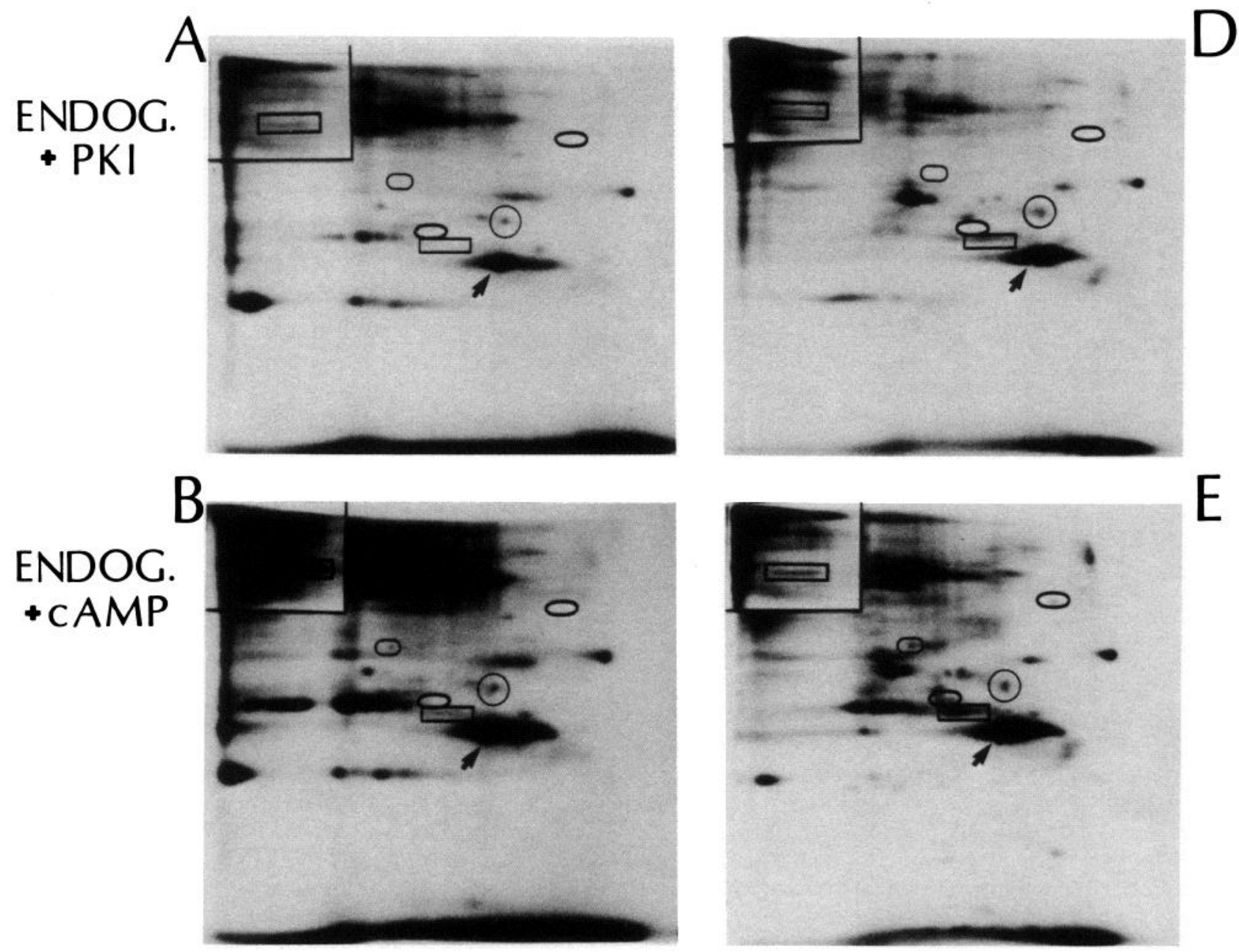

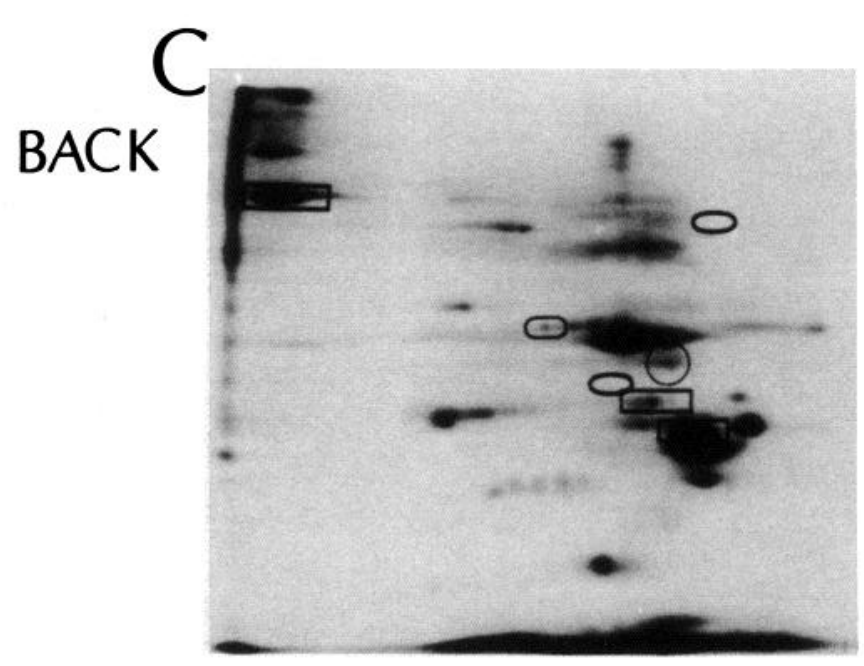

Particulate

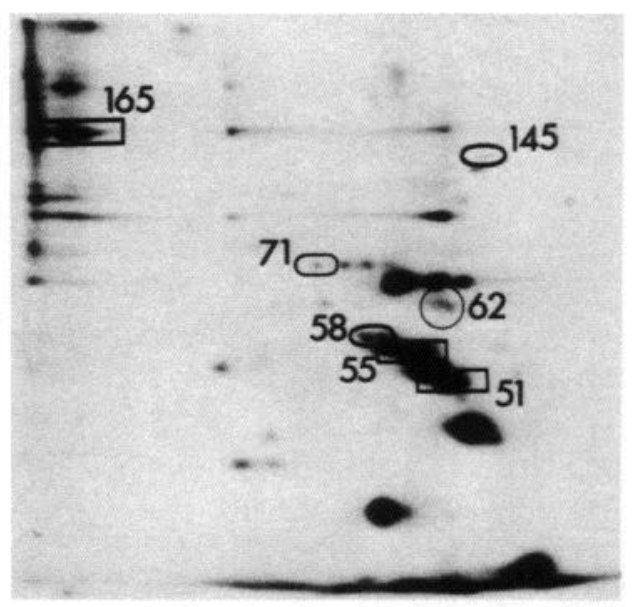

Soluble

Figure 7. Autoradiograms of 2-dimensional gels illustrating the subcellular distribution and endogenous phosphorylation of LC phosphoproteins. Particulate (gels $A, B, C$ ) and soluble (gels $D, E, F$ ) fractions were prepared from isolated LC nuclei and subjected to back phosphorylation (gels $C$ and $F$ ), or to endogenous phosphorylation in the presence of protein kinase inhibitor (ENDOG. $+P K I$, gels $A$ and $D)$ or 8-bromo-cAMP $(E N D O G$. $+c A M P$, gels $B$ and $E$ ), as described in Materials and Methods. Phosphorylated samples were then subjected to 2-dimensional gel electrophoresis (with $7.5 \%$ acrylamide in the second dimension), and resulting gels were dried and autoradiographed. Resulting autoradiograms are shown in their entirety; the boxes in the upper left corner of gels $A, B, D$, and $E$ represent lighter exposures of the autoradiograms in order to maximize visualization of individual phosphoproteins. The figure illustrates that $145 \mathrm{kDa}$ and $58 \mathrm{kDa}$ are localized to the soluble fraction, where they are endogenous 
phosphorylated 14-20 kDa has been demonstrated by comigration on 2-dimensional electrophoresis and by immunochemical methods (Guitart and Nestler, 1990).]

The situation was different for $51 \mathrm{kDa}$. This protein was not obviously demonstrated by endogenous phosphorylation, because a major phosphoprotein, tentatively identified as type II regulatory subunit of cAMP-dependent protein kinase, migrated in the vicinity of $51 \mathrm{kDa}$ (Fig. 7, gels A, B, D, and E). Peptide mapping of the $51 \mathrm{kDa}$ region of endogenous-phosphorylated gels revealed only a minor phosphopeptide fragment that corresponded to a fragment derived from back phosphorylated 51 $\mathrm{kDa}$ (see Fig. 8). Whether this minor fragment is derived from a low level of phosphorylated $51 \mathrm{kDa}$ or from another protein remains unknown. Therefore, it is uncertain whether $51 \mathrm{kDa}$ is phosphorylated by endogenous protein kinase activity in the LC under basal conditions.

\section{Discussion}

The results of the present study demonstrate that acute and chronic morphine alters the back-phosphorylation levels of a number of phosphoproteins in the rat LC. These actions of morphine were blocked by concomitant exposure to opiate receptor antagonists, indicating that the effects of acute and chronic morphine are achieved through the specific activation of opiate receptors. We also show that most of the phosphoproteins regulated in the LC by acute and chronic morphine are physiological substrates for cAMP-dependent protein kinase: the phosphorylation of the proteins is stimulated by forskolin or cAMP analogs in intact LC nuclei and by cAMP in particulate and/or soluble fractions of this brain region. The phosphoproteins regulated by morphine and cAMP are designated "MARPPs"(morphine- and cAMP-regulated phosphoproteins$M_{\mathrm{r}}$ ) according to standard conventions (see Walaas and Greengard, 1984) and include MARPPs- $165,-145,-71,-58,-55$, and -14-20. The 2 phosphoproteins regulated by morphine, but not by cAMP, are designated "MRPPs" and include MRPPs- 62 and -51 .

The morphine-induced changes in protein phosphorylation identified in this study were revealed by direct and indirect backphosphorylation procedures. Direct and indirect assays tend to measure different parameters of phosphoproteins (see Nestler and Greengard, 1984). In indirect back phosphorylation, brain tissue is homogenized in a buffer at physiological $\mathrm{pH}$, conditions under which several known phosphoproteins have been shown to be largely dephosphorylated by endogenous protein phosphatases. The homogenates are then acidified to inactivate protein kinase and protein phosphatase activities, neutralized, and back phosphorylated with purified cAMP-dependent protein kinase. Since phosphoproteins tend to be in their dephosphorylated forms in the final tissue extracts, indirect back phosphorylation is an indication of the total amounts of individual phosphoproteins. In contrast, in direct back phosphorylation, brain tissue is homogenized directly in an acidic buffer, which eliminates or at least reduces dephosphorylation that occurs during tissue preparation. Direct back phosphorylation, then, is an indication of the amount of individual phosphoproteins present in the tissue extracts (and in the original intact tissue) in their dephosphorylated form. This means that if the total amount of a protein remains constant (e.g., as indicated by no change in its indirect back phosphorylation), a decrease in its direct back phosphorylation would indicate a decrease in the amount of that protein in the dephosphorylated form, i.e., an increase in its phosphorylation state.

Based on these interpretations of back phosphorylation data, the results of the present study suggest, as summarized in Table 3 , that chronic morphine increases the phosphorylation state and/or total amount of the MARPPs and MRPPs, whereas acute morphine decreases the phosphorylation state of these proteins. Thus, chronic morphine decreased direct back phosphorylation levels of MARPPs- $165,-55$, and -14-20 without changes in their indirect back phosphorylation. It would appear that chronic morphine increased the phosphorylation state of these proteins without altering their total amounts. In contrast, chronic morphine produced similar increases in direct and indirect backphosphorylation levels of MARPPs- 145 and -58 and MRPP51 , indicating that chronic morphine increased the total amounts of these proteins, apparently with little or no change in phosphorylation state. Finally, chronic morphine increased indirect back phosphorylation levels of MRPP-62 and MARPP-71, with a decrease or no change, respectively, in their direct back phosphorylation, indicating that chronic morphine probably increased the total amount and phosphorylation state of these proteins.

In contrast to chronic morphine, acute morphine increased direct back-phosphorylation levels of MARPPs-165, $-145,-71$, $-58,-55$, and $-14-20$ and of MRPP-51, without changes in their indirect back phosphorylation. It would appear, then, that acute morphine decreased the state of phosphorylation of these proteins. Along analogous lines, the acute forskolin-induced decreases in direct back-phosphorylation levels of MARPPs-165, $-145,-71,-58,-55$, and $-14-20$, without changes in their indirect back phosphorylation, probably reflect increases in their state of phosphorylation. Since forskolin would be expected to activate cAMP-dependent protein kinase in intact LC nuclei by increasing cellular levels of cAMP, the data are consistent with the interpretation that the forskolin-induced increases in the phosphorylation state of these MARPPs are mediated through the activation of cAMP-dependent protein kinase. Further evidence that these phosphoproteins are endogenous substrates for this protein kinase is the demonstration that their phosphorylation is stimulated by the addition of cAMP to broken cell preparations of the LC.

Clearly, these various interpretations of back phosphorylation data need to be viewed with caution. For example, it is important to note that the interpretations are based on previous studies of well-characterized phosphoproteins and may not hold true for all phosphoproteins. Nevertheless, the number of phosphoproteins whose phosphorylation state and total amount can bc assessed accurately by direct and indirect back-phosphorylation

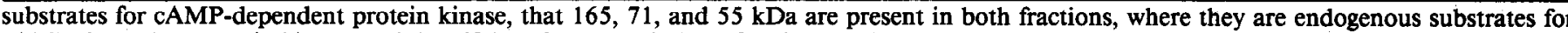

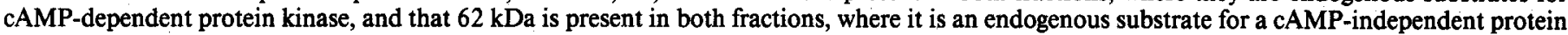

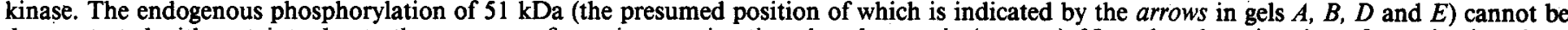

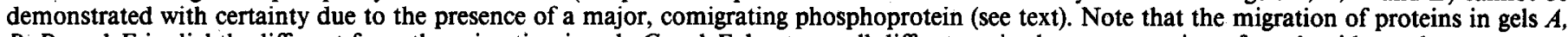
$B, D$, and $E$ is slightly different from the migration in gels $C$ and $F$ due to small differences in the concentration of acrylamide used. 
MARPP-165

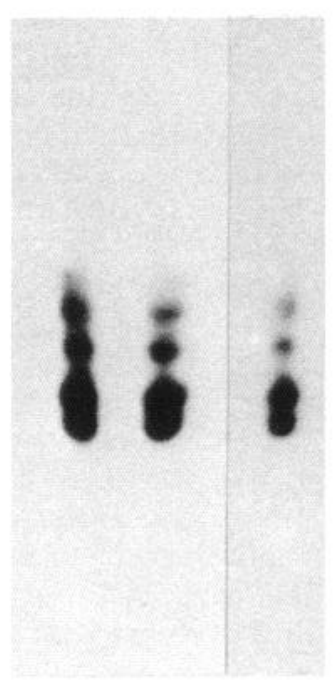

A B C
MARPP-145

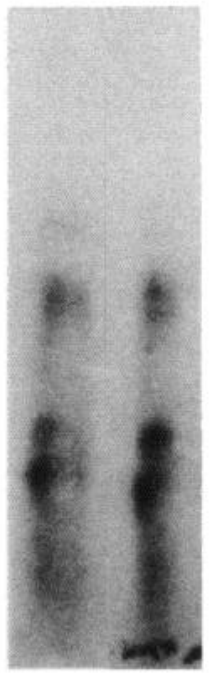

A

B
MARPP-58

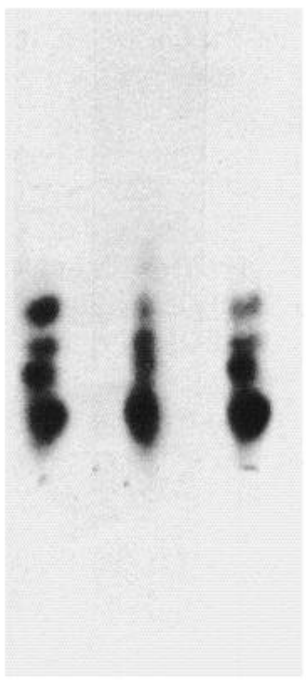

A B C

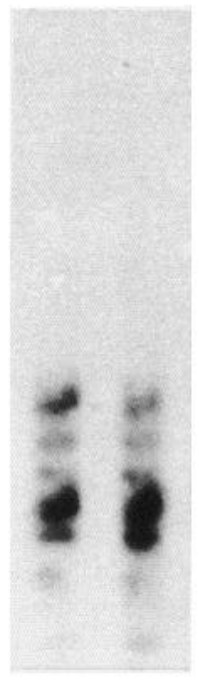

A B
MARPP-55

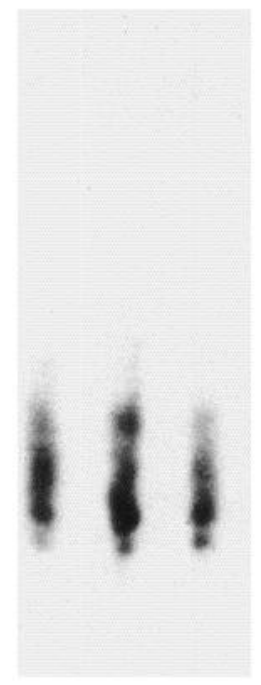

A B C
MARPP-71

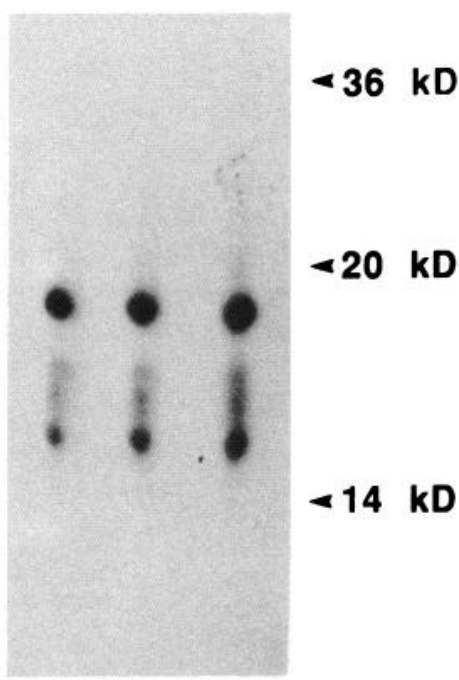

A B

\section{D}


Table 3. Summary of the regulation and subcellular distribution of morphine- and cAMP-regulated phosphoproteins

\begin{tabular}{|c|c|c|c|c|c|c|}
\hline & Chronic $\mathrm{mc}$ & orphine & Acute & $\begin{array}{l}\text { Acute } \\
\text { forskolin }\end{array}$ & $\begin{array}{l}\text { cAMP } \\
\text { kinase }\end{array}$ & $\begin{array}{l}\text { Sub- } \\
\text { cellular } \\
\text { distribu- }\end{array}$ \\
\hline & $\overline{\Delta \text { phosph. }}$ & $\Delta$ total & $\Delta$ phosph. & $\Delta$ phosph. & substrate & tion $^{a}$ \\
\hline MARPP-165 & $\uparrow$ & 0 & $\downarrow$ & $\uparrow$ & yes & $P \& S$ \\
\hline MARPP-145 & 0 & $\uparrow$ & $\downarrow$ & $\uparrow$ & yes & $\mathbf{S}$ \\
\hline MARPP-71 & $\uparrow$ & $\uparrow$ & $\downarrow$ & $\uparrow$ & yes & $P \& S$ \\
\hline MRPP-62 & $\uparrow$ & $\uparrow$ & 0 & 0 & no & $P \& S$ \\
\hline MARPP-58 & 0 & $\uparrow$ & $\downarrow$ & $\uparrow$ & yes & $\mathbf{S}$ \\
\hline MARPP-55 & $\uparrow$ & 0 & $\downarrow$ & $\uparrow$ & yes & $P \& S$ \\
\hline MRPP-51 & 0 & $\uparrow$ & $\downarrow$ & 0 & no & $P \& S$ \\
\hline MARPP-14-20 & $\uparrow$ & 0 & $\downarrow$ & $\uparrow$ & yes & $\mathbf{P}$ \\
\hline
\end{tabular}

Arrows indicate increases and decreases, and zeros no change, in the state of phosphorylation or total amount of the proteins induced by chronic morphine in vivo or by acute morphine or forskolin ex vivo. See text for discussion. a $=$ particulate; $\mathbf{S}=$ soluble.

ways (see Satoh et al., 1976; Dafny et al., 1979). It is possible that chronic morphine produces changes in protein phosphorylation in a subpopulation of cortical or striatal neurons similar to those produced in the LC, but that the changes are not detectable when the cortex or striatum as a whole is analyzed by biochemical procedures. It is also possible that LC neurons are different from certain other neurons in their responsiveness to opiates and that the various morphine-regulated phosphoproteins underlie such unique responsiveness. For example, the dorsal raphe, like the $\mathrm{LC}$, is homogeneous, but, unlike the $\mathrm{LC}$, it contains serotonergic neurons that do not respond to morphine acutely and do not develop morphine addiction based on electrophysiological criteria (G. K. Aghajanian, personal communication). Moreover, whereas most of the morphine-regulated phosphoproteins identified in the $\mathrm{LC}$ were present in all brain regions examined at similar levels, two of the proteins, namely, MARPP-58 and MRPP-62, showed more restricted distributions. Of particular potential interest is MRPP-62, whose presence in the LC at much higher levels compared to the other brain regions examined raises the possibility that it is enriched in LC neurons. It is possible that these region-specific phosphoproteins mediate some of the specific effects of chronic opiates on the LC. The results also suggest that the specific regulation of the various MARPPs and MRPPs by chronic morphine in the LC is not associated with a particular type of opiate receptor. Thus, the LC, like the dorsal raphe, contains primarily $\mu$ and $\kappa$ opiate receptors, whereas the neostriatum and frontal cortex contain $\mu, \kappa$, and $\delta$ opiate receptors (Tempel and Zukin, 1987; Mansour et al., 1988). Further work is needed to identify the type of opiate receptor, or one of its subtypes, in the LC through which morphine regulates the various MARPPs and MRPPs acutely and chronically, and to study the effects that more specific opiate agonists would have on protein phosphorylation. Finally, in contrast to the phosphoproteins that show specific regulation in the LC, MARPPs-145 and -14-20 show similar regulation in all of the brain regions studied. These may represent proteins common to many neuronal or glial cell types that respond to opiates in a similar fashion in all of those cells.

Regulation of the MARPPs and MRPPs by acute morphine and forskolin can be understood within a functional context. Acutely, opiates are known to inhibit LC neurons by increasing the conductance of a $\mathrm{K}^{+}$channel and by decreasing the con- ductance of a slowly depolarizing $\mathrm{Na}^{+}$channel (North and Williams, 1985; Aghajanian and Wang, 1987; North et al., 1987; Wang and Aghajanian, 1987). Both actions are achieved through pertussis toxin-inhibitable $\mathrm{G}$-proteins (i.e., $\mathrm{G}_{\mathrm{i} \alpha}$ and $\mathrm{G}_{\mathrm{oc}}$ ) (Aghajanian and Wang, 1986; North et al., 1987), whereas only the effect on the $\mathrm{Na}^{+}$channel appears to be mediated through reduced neuronal levels of cAMP (Andrade and Aghajanian, 1985; Aghajanian and Wang, 1987; Wang and Aghajanian, 1987). Reduced levels of cAMP would be expected to lead to decreased levels of activated cAMP-dependent protein kinase and to decreases in the phosphorylation state of specific substrates for the protein kinase. Acute opiate inhibition of adenylate cyclase has been demonstrated in the LC (Duman et al., 1988), and the present study provides the first direct biochemical evidence that opiates acutely inhibit cAMP-dependent protein phosphorylation in this brain region. Thus, the morphine-induced decreases in the phosphorylation state of MARPPs-165, $-145,-71,-58$, -55 , and $-14-20$, and forskolin's ability to reverse these changes, are consistent with the scheme that morphine produces these changes by decreasing adenylate cyclase activity and by consequently decreasing levels of cAMP and of activated cAMPdependent protein kinase. Reduced phosphorylation states of these, or other phosphoproteins not yet detected, presumably mediate the effect of morphine on inhibiting the slowly depolarizing $\mathrm{Na}^{+}$channel and probably also mediate many other effects of morphine on LC neuronal function. Such additional effects could include morphine regulation of neurotransmitter synthesis, neurotransmitter receptors, and the general metabolic state of the neurons (see Nestler and Greengard, 1984; Loh et al., 1988). The ability of acute morphine to regulate protein phosphorylation in the LC raises the possibility that the synaptic actions of endogenous opioid neurotransmitters known to innervate the LC (Simantov et al., 1977; Zamir et al., 1985) are mediated in part through protein phosphorylation. The results of the present study add opioids to a growing number of neurotransmitters that are known to regulate protein phosphorylation in target neurons (see Nestler and Greengard, 1984, 1989; Gispen and Routtenberg, 1986; Kaczmarek and Levitan, 1986; Schwartz and Greenberg, 1987).

In contrast to the MARPPs discussed above, MRPP-51 and -62 do not appear to be endogenous substrates for cAMP-dependent protein kinase in broken cell preparations of the LC. 
Presumably, these proteins are back phosphorylated by exogenous cAMP-dependent protein kinase due to the high concentrations of the protein kinase used in the assay, conditions known to result in the phosphorylation of proteins that are not physiological substrates for this enzyme (see Nestler and Greengard, 1984). The ability of acute morphine to decrease MRPP-51 phosphorylation in intact LC nuclei suggests that morphine inhibits the activity of another type of protein kinase (or stimulates the activity of a protein phosphatase) in this brain region. MRPP62 , which is regulated by chronic morphine, is not regulated by acute morphine in intact LC nuclei. The protein does, however, appear to be a substrate for an as yet unidentified endogenous protein kinase activity in this brain region (see Fig. 7). Identification of the protein kinases, protein phosphatases, or other intracellular messengers involved in morphine regulation of MRPPs-62 and -51 will yield important information concerning the types of intracellular second messenger systems, in addition to the cAMP system, that are regulated by morphine in target neurons. Similarly, it will be interesting to determine whether the various MARPPs identified in this study are physiological substrates for protein kinases in addition to the cAMP-dependent enzyme, as many phosphoproteins identified to date have been shown to be phosphorylated by more than one protein kinase (see Nestler and Greengard, 1984, 1989).

Among the most striking findings of the present study are the observations that phosphoproteins, whose state of phosphorylation is decreased by morphine in the LC acutely, show increased phosphorylation states and/or total amounts in this brain region in response to chronic morphine (see Table 3). Such regulation of the MARPPs and MRPPs by chronic morphine could be viewed as a negative feedback pathway through which LC neurons adapt to persistent opiate inhibition of the cells. Chronically, persistent reduced phosphorylation states of the phosphoproteins could trigger a cascade of events by which LC neurons attempt to overcome morphine's actions and return toward a basal state. Earlier studies have shown that such a cascade includes increases in levels of $G_{i \alpha}$ and $G_{o \alpha}$ (Nestler et al., 1989), adenylate cyclase activity (Duman et al., 1988), and cAMP-dependent protein kinase activity (Nestler and Tallman, 1988). The present study now demonstrates that the cascade also includes increased levels of phosphorylation state and/or total amount of specific substrates for CAMP-dependent protein kinase. Increased levels of phosphorylation of MARPPs-165 and -55 , effects specific to the LC, could reflect the increased levels of cAMP-dependent protein kinase activity that occur specifically in the $\mathrm{LC}$ in response to chronic morphine. In contrast, increased levels of phosphorylation of MARPP-14-20, an effect common to all regions studied, cannot be explained by increased protein kinase activity, since the increase in enzyme activity does not occur in these other brain regions. The mechanism underlying chronic morphine regulation of MARPP-1420 , therefore, requires further investigation. Changes in the other MARPPs (MARPPs-145, -71, and -58) appear to reflect increased lcvels of the total amounts of these phosphoproteins, results which support previous demonstrations that chronic morphine can alter de novo protein synthesis in brain (e.g., see Lee et al., 1975; Hook et al., 1981; Retz and Steele, 1982; Mohanakumar and Sord, 1986; Ronnback and Hansson, 1986; Kornblum et al., 1987). In contrast to the MARPPs, chronic morphine regulation of MRPPs-62 and -51 , which also appear to represent increases in the total amounts of these proteins, presumably reflects adaptations of LC neurons to chronic morphine that are mediated through cAMP-independent pathways.

The data raise the possibility that chronic morphine regulates protein phosphorylation in the LC by 2 general mechanisms: by increasing the total amounts of specific phosphoproteins or by increasing the phosphorylation states of constant amounts of other phosphoproteins. This raises the possibility that these 2 mechanisms could underlie different aspects of morphine addiction and thereby explain the widely different time courses of various opiate withdrawal symptoms (see Redmond and Krystal, 1984; Beitner et al., 1989). Thus, alterations in phosphorylation state would be expected to recover to normal levels during opiate withdrawal much more rapidly than changes in total amount, suggesting that alterations in phosphorylation state may be involved in symptoms of immediate opiate withdrawal, whereas alterations in total amount may be involved in symptoms of protracted withdrawal.

A major focus of future studies will be to determine the nature of the MARPPs and MRPPs identified in the current studies. In subsequent publications, we will demonstrate that MARPP58 corresponds to tyrosine hydroxylase and that MARPP-14-20 corresponds to myclin basic proteins (Guitart and Nestler, 1990 and unpublished observations). The nature of the other MARPPs and MRPPs, which do not appear to correspond to some other previously characterized phosphoproteins based on their migration on 2-dimensional gels, awaits further study. Through the characterization of these various morphine- and cAMP-regulated phosphoproteins it will be possible to build a progressively more complete understanding of the precise molecular steps underlying the development and expression of morphine addiction in the nervous system.

\section{References}

Aghajanian, G. K. (1978) Tolerance of locus coeruleus neurones to morphine and suppression of withdrawal response by clonidine. Nature 267: 186-188.

Aghajanian, G. K., and Y.-Y. Wang (1986) Pertussis toxin blocks the outward currents evoked by opiate and $\alpha_{2}$-agonists in locus coeruleus neurons. Brain Res. 371: 390-394.

Aghajanian, G. K., and Y.-Y. Wang (1987) Common alpha-2 and opiate effector mechanisms in the locus coeruleus: Intracellular studies in brain slices. Neuropharmacology 26: 789-800.

Andrade, R., and G. K. Aghajanian (1985) Opiate and $\alpha_{2}$-adrenoreceptor-induced hyperpolarization of locus coeruleus neurons in brain slices: Reversal by cyclic-AMP analogs. J. Neurosci. 5: 2359-2364.

Beitner, D. B., K. Rasmussen, J. H. Krystal, G. K. Aghajanian, and E. J. Nestler (1989) Studies of opiate withdrawal in the rat locus coeruleus: Correlations of behavioral, electrophysiological, and biochemical studies. Soc. Neurosci. Abstr. 15: 143.

Blasig, J., A. Herz, K. Reinhold, and S. Zieglgansberger (1973) Development of physical dependence on morphine in respect to time and dosage and quantification of the precipitated withdrawal syndrome in rats. Psychopharmacologia 33: 19-38.

Browning, M. D., C.-K. Huang, and P. Greengard (1987) Similarities between protein IIIa and protein IIIb. J. Neurosci. 7: 847-853.

Christie, M. J., J. T. Williams, and R. A. North (1987) Cellular mechanisms of opioid tolerance: Studies in single brain neurons. Mol. Pharmacol. 32: 633-638.

Cleveland, D. W., S. G. Fischer, M. W. Kirschner, and U. K. Laemmli (1977) Peptide mapping by limited proteolysis in sodium dodecyl sulfate and analysis by gel electrophoresis. J. Biol. Chem. 252: 11021106.

Dafny, N., M. Brown, T. J. Burks, and B. M. Rigor (1979) Morphine tolerance and dependence: Sensitivity of caudate nucleus neurons. Brain Res. 162: 363-368.

Dolphin, A. C., and P. Greengard (1981) Neurotransmitter and neu- 
romodulator-dependent alterations in phosphorylation of Protein I in slices of rat facial nucleus. J. Neurosci. $1: 192-203$.

Duman, R. S., J. F. Tallman, and E. J. Nestler (1988) Acute and chronic opiate-regulation of adenylate cyclase in brain: Specific effects in locus coeruleus. J. Pharmacol. Exp. Ther. 246: 1033-1039.

Foote, S. L., F. E. Bloom, and G. Aston-Jones (1983) Nucleus locus coeruleus: New evidence of anatomical and physiological specificity. Physiol. Rev. 63: 844-914.

Forn, J., and P. Greengard (1978) Depolarizing agents and cyclic nucleotides regulate the phosphorylation of specific neuronal proteins in rat cerebral cortex slices. Proc. Natl. Acad. Sci. USA 75: 51955199.

Girault, J.-A., I. A. Shalaby, N. L. Rosen, and P. Greengard (1988) Regulation by cAMP and vasoactive intestinal peptide of phosphorylation of specific proteins in striatal cells in culture. Proc. Natl. Acad. Sci. USA 85: 7790-7794.

Gispen, W. H., and A. Routtenberg, eds. (1986) Phosphoproteins in Neuronal Function. Vol. 69, Progress in Brain Research.

Grant, S. J., Y. H. Huang, and D. E. Redmond, Jr. (1988) Behavior of monkeys during opiate withdrawal and locus coeruleus stimulation. Pharmacol. Biochem. Behav. 30: 13-19.

Guitart, X., and E. J. Nestler (1990) Identification of MARPP-14-20, morphine- and cyclic AMP-regulated phosphoproteins of $14-20 \mathrm{kD}$, as myelin basic proteins: Evidence for their acute and chronic regulation by morphine in rat brain. Brain Res. (in press).

Hook, V. Y., K. B. Stokes, N. M. Lee, and H. H. Loh (1981) Possible nuclear protein kinase regulation of homologous ribonucleic acid polymerases from small dense nuclei of mouse brain during morphine tolerance-dependence. Involvement of cyclic 3',5'-adenosine monophosphate. Biochem. Pharmacol. 30: 2313-2318.

Kaczmarek, L. K., and I. B. Levitan (1986) Neuromodulation: The Biochemical Control of Neuronal Excitability, Oxford U. P., New York.

Kornblum, H. I., S. E. Loughlin, and F. M. Leslie (1987) Effects of morphine on DNA synthesis in neonatal rat brain. Dev. Brain Res. 31: $45-52$.

Laemmli, U. K. (1970) Cleavage of structural proteins during the assembly of the head of bacteriophage T4. Nature 227: 680-685.

Lee, N. M., I. Ho, and H. H. Loh (1975) Effect of chronic morphine treatment on brain chromatin template activities in mice. Biochem. Pharmacol. 21: 1983-1987.

Loh, H. H., P.-L. Tao, and A. P. Smith (1988) Invited review: Role of receptor regulation in opioid tolerance mechanisms. Synapse 2: 457-462.

Lowry, O. H., N. J. Rosebrough, A. L. Farr, and R. J. Randall (1951) Protein measurement with the folin phenol reagent. J. Biol. Chem. 193: 265-275

Mansour, A., H. Khachaturian, M. E. Lewis, H. Akil, and S. J. Watson (1988) Anatomy of CNS opioid receptors. Trends Neurosci. 11: 308314.

Mohanakumar, K. P., and P. P. Sord (1986) Changes in ribonuclease in the central nervous system of mice during morphine dependence, withdrawal and naloxone administration. Clin. Physiol. Biochem. 4. 159-163.

Nestler, E. J., and P. Greengard (1980) Dopamine and depolarizing agents regulate the state of phosphorylation of Protein I in the mammalian superior cervical sympathetic ganglion. Proc. Natl. Acad. Sci. USA 77: 7479-7483.

Nestler, E. J., and P. Greengard (1982) Distribution of Protein I and regulation of its state of phosphorylation in the rabbit superior cervical ganglion. J. Neurosci. 2: 1011-1023.

Nestler, E. J., and P. Greengard (1984) Protein Phosphorylation in the Nervous System, Wiley, New York.
Nestler, E. J., and P. Greengard (1986) Synapsin I: A review of its distribution and biological regulation. Prog. Brain Res. 69: 323-339.

Nestler, E. J., and P. Greengard (1989) Protein phosphorylation and the regulation of neuronal function. In Basic Neurochemistry: Molecular, Cellular, and Medical Aspects, G. J. Siegel, B. Agranoff, R. W. Albers, and P. Molinoff, eds., pp. 373-398, Raven, New York.

Nestler, E. J., and J. F. Tallman (1988) Chronic morphine treatment increases cyclic AMP-dependent protein kinase activity in the rat locus coeruleus. Mol. Pharmacol. 33: 127-132.

Nestler, E. J., R. Terwilliger, J. J. Erdos, R. S. Duman, and J. F. Tallman (1989) Regulation by chronic morphine of G-proteins in the rat locus coeruleus. Brain Res. 476: 230-239.

North, R. A., and J. T. Williams (1985) On the potassium conductance increased by opioids in rat locus coeruleus neurones. J. Physiol. 364: 265-280.

North, R. A., J. T. Williams, A. Suprenant, and M. J. Christie (1987) $\mathrm{Mu}$ and delta receptors belong to a family of receptors that are coupled to potassium channels. Proc. Natl. Acad. Sci. USA 84: 54875491 .

O'Farrell, P. H. (1975) High resolution two-dimensional electrophoresis of proteins. J. Biol. Chem. 250: 4007-4021.

Redmond, D. E., Jr., and J. H. Krystal (1984) Multiple mechanisms of withdrawal from opioid drugs. Annu. Rev. Neurosci. 7: 443-478.

Retz, K. C., and W. J. Steele (1982) Mechanism of inhibition of protein synthesis by morphine in rat brain and liver. Mol. Pharmacol. 22: 706-714.

Ronnback, L., and E. Hansson (1986) Stimulation of brain-stem protein synthesis by morphine. Biochem. Pharmacol. 35: 3685-3692.

Satoh, M., W. Zieglgansberger, and A. Herz (1976) Actions of opiates upon single unit activity in the cortex of naive and tolerant rats. Brain Res. 115: 99-110.

Schwartz, J. H., and S. M. Greenberg (1987) Molecular mechanisms for memory: Second messenger induced modifications of protein kinase in nerve cells. Annu. Rev. Neurosci. 10: 459-476.

Simantov, R., M. J. Kuhar, G. R. Uhl, and S. H. Snyder (1977) Opioid peptide enkephalin: Immunohistochemical mapping in rat central nervous system. Proc. Natl. Acad. Sci. USA 74: 2167-2171.

Tempel, A., and R. S. Zukin (1987) Neuroanatomical patterns of the $\mu, \delta$, and $\kappa$ opioid receptors of rat brain as determined by quantitative in vitro autoradiography. Proc. Natl. Acad. Sci. USA 84: 4308-4312.

Tsou, K., and P. Greengard (1982) Regulation of phosphorylation of Proteins I, IIIa, and IIIb in rat neurohypophysis in vitro by electrical stimulation and by neuroactive agents. Proc. Natl. Acad. Sci. USA 79: 6075-6079.

Walaas, S. I., and P. Greengard (1984) DARPP-32, a dopamine- and cyclic AMP-regulated phosphoprotein enriched in dopamine-innervated brain regions. I. Regional and cellular distribution in the rat brain. J. Neurosci. 4: 84-98.

Walaas, S. I., A. C. Nairn, and P. Greengard (1983) Regional distribution of calcium- and cyclic AMP-regulated protein phosphorylation systems in mammalian brain. I. Particulate systems. J. Neurosci. 3: 291-301.

Walaas, S. I., A. C. Nairn, and P. Greengard (1986) PCPP-260, a Purkinje cell-specific cyclic AMP-regulated membrane phosphoprotein of $M_{r}$ 260,000. J. Neurosci. 6: 954-961.

Wang, Y.-Y., and G. K. Aghajanian (1987) Excitation of locus coeruleus neurons by an adenosine $3^{\prime}, 5^{\prime}$-cyclic monophosphate-activated inward current: Extracellular and intracellular studies in rat brain slices. Synapse 1: 481-487.

Zamir, N., M. Palkovits, and M. Brownstein (1985) Distribution of immunoreactive metenkephalin-arg6 ${ }^{6}-$ gly $^{7}-$ leu $^{8}$ and leu-enkephalin in discrete regions of the rat brain. Brain Res. 326: 1-8. 